\title{
Origin of cross-chain geochemical variation in Quaternary lavas from the northern Izu arc: Using a quantitative mass balance approach to identify mantle sources and mantle wedge processes
}

\section{Jun-Ichi Kimura}

Institute for Research on Earth Evolution, Japan Agency for Marine-Earth Science and Technology, Yokosuka 237-0061, Japan (jkimura@jamstec.go.jp)

\section{Adam J. R. Kent}

Department of Geosciences, Oregon State University, 104 Wilkinson Hall, Corvallis, Oregon 97331-5506, USA (adam.kent@geo.oregonstate.edu)

\section{Michael C. Rowe}

Department of Geoscience, University of Iowa, Iowa City, Iowa 52242, USA

(michael-rowe@uiowa.edu)

Now at School of Earth and Environmental Sciences, Washington State University, 1228 Webster Physical Sciences Building, Pullman, Washington 99164, USA (mcrowe@wsu.edu)

\section{Maiko Katakuse}

Department of Geoscience, Shimane University, Matsue 690-8504, Japan

Now at Kansai Construction Survey Co., Ltd., Osaka 562-0035, Japan (maimai128@gmail.com)

\section{Fumi Nakano}

Department of Geoscience, Shimane University, Matsue 690-8504, Japan

\section{Bradley R. Hacker}

Department of Earth Science, University of California, Santa Barbara, California 93109-9630, USA (hacker@geol.ucsb.edu)

\section{Peter E. van Keken}

Department of Geological Sciences, University of Michigan, 1100 North University Avenue, Ann Arbor, Michigan 48109-1005, USA (keken@umich.edu)

\section{Hiroshi Kawabata}

Institute for Research on Earth Evolution, Japan Agency for Marine-Earth Science and Technology, Yokosuka 237-0061, Japan (biroshik@jamstec.go.jp)

\section{Robert J. Stern}

Department of Geosciences, University of Texas at Dallas, Richardson, Texas 75083-0688, USA (rjstern@utdallas.edu) 
[1] We present major, trace element, and $\mathrm{Pb}-\mathrm{Sr}-\mathrm{Nd}-\mathrm{Hf}$ isotope data for Quaternary basalt and basaltic andesite lavas from cross-chain volcanoes in the northern Izu (N-Izu) arc. Lavas from Izu-Oshima, Toshima, Udonejima, and Niijima islands show consistent chemical changes with depth to the Wadati-Benioff zone, from $120 \mathrm{~km}$ beneath Izu-Oshima to $180 \mathrm{~km}$ beneath Niijima. Lavas from Izu-Oshima at the volcanic front (VF) have elevated concentrations of large ion lithophile elements (LILEs), whereas rear-arc (RA) lavas are rich in light rare earth elements (LREEs) and high field strength elements (HFSEs). VF lavas also have more radiogenic $\mathrm{Pb}, \mathrm{Nd}, \mathrm{Sr}$, and $\mathrm{Hf}$ isotopic compositions. We have used the Arc Basalt Simulator version 3 (ABS3) to examine the mass balance of slab dehydration and melting and slab fluid/melt-fluxed mantle melting and to quantitatively evaluate magma genesis beneath N-Izu. The results suggest that the slab-derived fluids/melts are derived from $\sim 20 \%$ sediment and $\sim 80 \%$ altered oceanic crust, the slab fluid is generated by slab dehydration for the VF magmas at $3.3-3.5 \mathrm{GPa} / 660^{\circ} \mathrm{C}-700^{\circ} \mathrm{C}$, and slab melt for RA magmas is supplied at 3.4-4.4 GPa $/ 830^{\circ} \mathrm{C}-890^{\circ} \mathrm{C}$. The degree of fluxed melting of the mantle wedge varies between $17 \%$ and $28 \%(\mathrm{VF})$ and $6 \%$ and $22 \%$ (RA), with a slab flux fraction of $2 \%-4.5 \%$ (VF fluid) to $1 \%-1.5 \%$ (RA melt), and at melting depths 1-2.5 GPa (VF) and 2.4-2.8 GPa (RA). These conditions are consistent with a model whereby shallow, relatively low temperature slab fluids contribute to VF basalt genesis, whereas deeper and hotter slab melts control formation of RA basalts. The low-temperature slab dehydration is the cause of elevated $\mathrm{Ba} / \mathrm{Th}$ in VF basalt due mainly to breakdown of lawsonite, whereas deeper breakdown of phengite by slab melting is the cause of elevated $\mathrm{K}$ and $\mathrm{Rb}$ in RA basalts. Melting in the garnet stability field, and at lower degrees of partial melting, is required for the elevated LILEs, LREEs, and HFSEs observed in the $\mathrm{RA}$ basalts. Less radiogenic $\mathrm{Sr}, \mathrm{Nd}, \mathrm{Hf}$, and $\mathrm{Pb}$ in $\mathrm{RA}$ basalts are all attributable to lesser slab flux additions. The low $\mathrm{H}_{2} \mathrm{O}$ predicted for RA basalt magmas $(<1.5 \mathrm{wt} \%)$ relative to that in VF basalt magmas $(5-8 \mathrm{wt} \%)$ is also due to melt addition rather than fluid. All these conclusions are broadly consistent with existing models; however, in this study they are quantitatively confirmed by the geochemical mass balance deduced from petrological ABS3 model. Overall, the P-T-X $\left(\mathrm{H}_{2} \mathrm{O}\right)$ structure of the slab and the mantle wedge exert the primary controls on arc basalt genesis.

Components: 15,800 words, 8 figures, 2 tables.

Keywords: arc basalt; altered oceanic crust; mantle; partial melting; peridotite; slab.

Index Terms: 8410 Volcanology: Geochemical modeling $(1009,3610) ; 8413$ Volcanology: Subduction zone processes $(1031,3060,3613,8170)$.

Received 19 January 2010; Revised 19 August 2010; Accepted 24 August 2010; Published 15 October 2010.

Kimura, J.-I., A. J. R. Kent, M. C. Rowe, M. Katakuse, F. Nakano, B. R. Hacker, P. E. van Keken, H. Kawabata, and R. J. Stern (2010), Origin of cross-chain geochemical variation in Quaternary lavas from the northern Izu arc: Using a quantitative mass balance approach to identify mantle sources and mantle wedge processes, Geochem. Geophys. Geosyst., 11, Q10011, doi:10.1029/2010GC003050.

\section{Introduction}

[2] Arc basalt compositions frequently exhibit spatial variations across and along arcs [Elliott et al., 1997; Woodhead et al., 1993]. Although the ultimate source of along arc variations may be difficult to constrain due to along arc variations in the composition of subducted material [Carr et al., 2007; Jicha et al., 2004; Sadofsky et al., 2008; Stern et al., 2003], slab age and geometry [Kimura et al., 2005; Yogodzinski et al., 2001], and upper plate contributions [Kersting et al., 1996; Kimura and Yoshida, 2006], across arc variations are more broadly consistent and thus predictable. Studies on trace element and isotopic compositions of cross arc volcanic chains have the further advantage of minimizing the effects of source and slab variations, allowing models to focus on how slab processes vary with different depths within a single subduction zone. In most instances there are systematic increases in all incompatible elements, including large ion lithophile elements (LILEs), light rare earth elements (LREEs), high field strength elements (HFSEs), and alkalis from the volcanic front (VF) to the rear arc (RA), accompanied by systematic decreases in LILE/HFSE ratios [Arculus and Johnson, 1981; Churikova et al., 2001; Dickinson, 1975; Gill, 1981; Hatherton and Dickinson, 1969; Hochstaedter et al., 2001; Kimura and Yoshida, 2006; Moriguti et al., 


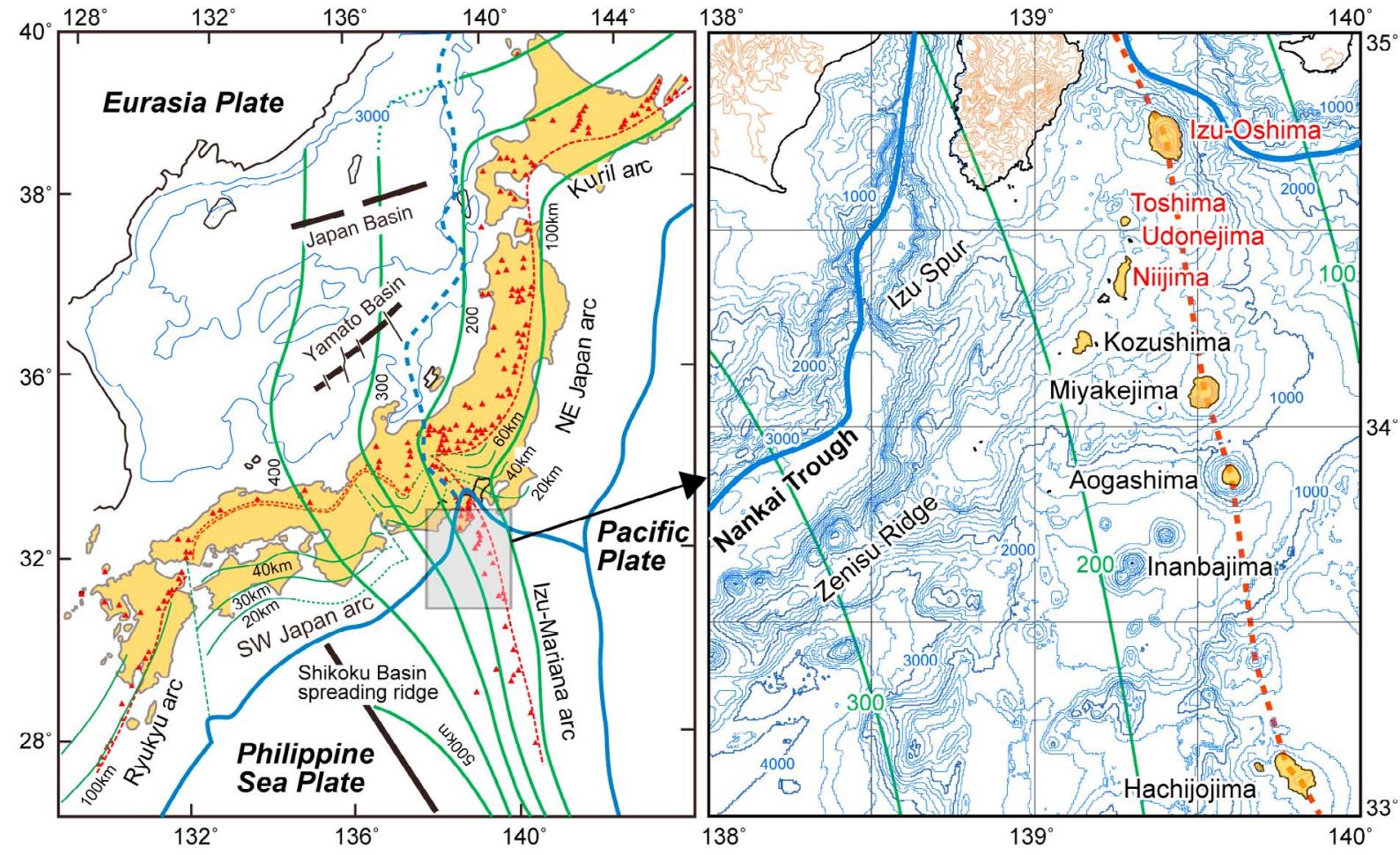

Figure 1. Location and tectonic setting of the northern Izu arc. (left) Thick blue line, trench; dotted thick blue line, North America and Eurasia Plate boundary; thick green line, depth contour of the Pacific Plate slab surface; thin green line, depth contour of the Philippine Sea Plate slab surface; thin dotted red line, volcanic front; thin blue line in the Japan Sea, depth contour; thick black line, spreading ridge; red triangle, Quaternary volcano. (right) Thick blue line, trench; thin blue line, depth contour; thick green line with number, depth contour of the Pacific Plate slab surface in $\mathrm{km}$; brown thin line, contours on land; thick dotted red line, volcanic front.

2004; Pearce et al., 1995; Pearce and Parkinson, 1993; Pearce et al., 2005; Peate et al., 1997; Sakuyama and Nesbitt, 1986; Shibata and Nakamura, 1997; Stern et al., 2003; Tamura et al., 2007; Tatsumi and Eggins, 1995]. Isotopic compositions also typically vary, with the transition from VF to RA marked by decreasingly radiogenic $\mathrm{Sr}, \mathrm{Nd}$, $\mathrm{Hf}$, and $\mathrm{Pb}$, although there are exceptions to this [Hochstaedter et al., 2001; Shibata and Nakamura, 1997; Tollstrup et al., 2010].

[3] The northern Izu arc (N-Izu) is in many respects a typical oceanic arc, and exhibits clear across-arc geochemical variations [Hochstaedter et al., 2001; Ishikawa and Tera, 1999; Ishizuka et al., 2003, 2006; Machida et al., 2008; Stern et al., 2003; Straub and Layne, 2003; Tamura et al., 2007; Taylor and Nesbitt, 1998; Tollstrup et al., 2010]. The cross chain of interest for this study extends to the southwest from Izu-Oshima (Figure 1), the largest mafic active volcano in the Izu arc, and includes four mafic to intermediate volcanoes behind the VF, Toshima, Udonejima and Niijima. These include the only RA volcanoes built above sea level in the entire Izu-Bonin-Mariana (IBM) arc. The relatively robust magmatic nature of this cross chain may reflect extensional stresses on the bending NW Philippine Sea plate as it is subducted beneath central Japan.

[4] Several geochemical and isotopic studies have been carried out on Izu cross-chain volcanoes. On the basis of trace element and isotopic compositions, Taylor and Nesbitt [1998] inferred that there was less slab contribution in RA lavas relative to those of the VF. Hochstaedter et al. [2001] proposed a semidynamic model whereby RA slab melt addition causes fluxed melting in the RA mantle, with the depleted RA mantle then convecting to beneath the $\mathrm{VF}$ and melting again due to greater slab fluid addition to form VF basalt. Ishizuka et al. [2006] concluded that slab fluid affected the VF basalt source, whereas slab melt was more important for forming RA basalt magmas. Tamura et al. [2007] suggested phengite breakdown best explained high $\mathrm{K}$ contents in Izu RA basalts. Machida et al. [2008] 
examined fluid-fluxed mantle melting and found differences in the slab flux addition between VF and RA. Control of magma compositions by variations in mantle source compositions has also been suggested by Ishizuka et al. [2003]. Recently, Tollstrup et al. [2010], in a study of lavas from the southern Izu arc lavas used inversion calculations to elucidate source mantle and slab flux chemistry and suggested that the source mantle composition was less heterogeneous than previously suggested, but that a transition from slab-derived aqueous fluids beneath the VF to supercritical fluids beneath the RA were the primary source of across arc variations.

[5] To date only qualitative or semiquantitative approaches have been applied in evaluating the contributions of different mantle/fluid/melt sources in the Izu arc, and fully integrated mass balance calculations of slab dehydration/melting and fluxed mantle melting within the mantle wedge have not been applied. Here we report a new geochemical data set including major and minor elements, trace elements determined by ICP-MS, and $\mathrm{Sr}-\mathrm{Nd}-\mathrm{Hf}-\mathrm{Pb}$ isotope compositions on basalt and basaltic andesite lavas from the Izu-Oshima, Toshima, Udonejima, and Niijima chain (Figure 1). In concert with this data set, mass balance calculations have been performed using the Arc Basalt Simulator version 3 (ABS3), an algorithm developed for quantitative mass balance modeling of subduction related magmatism. ABS3 is an improved version of the ABS2 model that has been reported elsewhere [Kimura et al., 2009]. We use ABS3 modeling to infer intensive and extensive variables in the slab and constrain the mantle processes that lead to subduction zone basalt genesis for the Oshima-Niijima cross-chain magmatic system. This is the first application of the ABS (including ABS2 and ABS3) mass balance model to an oceanic arc where the effect of crustal contamination is believed to be minimal.

\section{Geological Background and Samples}

[6] The N-Izu volcanic chain is the result of subduction of the Pacific Plate beneath the Philippine Sea plate. The Pacific Plate adjacent to the trench was formed at 120-130 Ma [Nakanishi et al., 1992] and the plate currently subducts at a rate of $\sim 10 \mathrm{~cm} /$ year [Seno et al., 1993]. The subduction angle of the Pacific Plate (hereafter referred to as "slab") is steepened from $20^{\circ}$ beneath the fore arc through $45^{\circ}$ beneath the volcanic front to $\sim 60^{\circ}$ beneath the rear arc. The slab is traceable by seismic activity down to the $550 \mathrm{~km}$ mantle transition zone depth at a distance of $\sim 400 \mathrm{~km}$ behind the trench [Seno et al., 1993; Stern et al., 2003]. This study focuses on a cross-arc island chain, located behind the VF volcano of Izu-Oshima (Figure 1). Along this chain the depths to the slab surface range from $\sim 120 \mathrm{~km}$ at the VF (Izu-Oshima) to $\sim 180 \mathrm{~km}$ (Toshima, Udonejima, Niijima; Figure 1). Izu arc volcanoes are built on $\sim 25 \mathrm{~km}$ thick arc crust, which formed by magmatic additions in an oceanic environment over the past $\sim 48$ million years [Kodaira et al., 2007; Stern et al., 2003].

[7] Quaternary volcanoes of interest to this study belong to a late Cenozoic volcanic cross chain that developed on the NE part of the Zenisu Ridge [Ishizuka et al., 2003] (Figure 1). The ages of Zenisu Ridge volcanic rocks and the Quaternary Izu-Oshima to Niijima cross chain show younging from the RA to VF. The ages range from $6.4 \pm$ $0.12 \mathrm{Ma}$ through $5.77 \pm 0.05 \mathrm{Ma}, 2.58 \pm 0.06 \mathrm{Ma}$, $2.01 \pm 0.05 \mathrm{Ma}$ on the Zenisu Ridge, to historical and present-day eruptions at Quaternary RA and VF volcanoes [Ishizuka et al., 2006]. No evidence of volcanic activity is recognized in the Izu VF before 10 Ma [Isshiki, 1977, 1984, 1986]. This may reflect cessation of spreading in the Shikoku Basin back arc basin (BAB) $\sim 15$ Ma [Okino et al., 1994] leading to establishment of the present N-Izu volcanic arc [Ishizuka et al., 2003]. Beyond the study area, there has been rifting in the southern part of the Izu arc since $\sim 5 \mathrm{Ma}$ [Ishizuka et al., 2006], although systematic across arc geochemical variations appears to be disturbed perhaps due to upwelling of deep asthenosphere beneath the rift zone [Hochstaedter et al., 2001; Machida et al., 2008]. There is no evidence of rifting in the northernmost Izu arc, where our study is focused.

[8] For this study we have sampled Quaternary basalt to basaltic andesite lavas and tuffs from IzuOshima, Toshima, Udonejima, and Niijima islands (Figure 1). Izu-Oshima, Toshima, and Udonejima consist largely of basalt to basaltic andesite lavas [Isshiki, 1977, 1984, 1986]. Niijima consists largely of dacite to rhyolite lava domes and pyroclastics, although a mafic tuff ring volcano surrounding the Wakago Bay erupted basaltic andesite scoria [Isshiki, 1986]. Overall, the basalts to basaltic andesites used in this study were all erupted in the late Quaternary, and thus represent a relatively recent cross-chain sample set. The basalt to basaltic andesite lavas from Izu-Oshima are all younger than $20 \mathrm{ka}$ [Isshiki, 1984]. Most lavas are historical and the latest eruption occurred in 1986 [Nakano and Yamamoto, 1991]. Toshima is located immediately on the RA side of Izu-Oshima. This island also consists of 
lavas and pyroclastics of basalt to basaltic andesite composition. Radiocarbon dating of soils developed on volcanic surfaces suggest ages of about $7 \mathrm{ka}$ [Isshiki, 1977]. Udonejima is an isolated and unpopulated island which consists of alternating lavas and pyroclastics with numerous feeder dikes. Udonejima volcano is dissected, suggesting a somewhat older age, although there are no radiometric age determinations. The estimated age of the volcano is a few tens of thousand years based on its morphology [Isshiki, 1986]. The Wakago tuff ring deposits on Niijima are younger than 3 ka [Isshiki, 1986].

[9] We report data for 58 samples, including 20 from Izu-Oshima, 19 from Toshima, 14 from Udonejima, and 5 mafic scoria samples from Niijima. All 58 samples were analyzed for major and trace elements by X-ray fluorescence spectrometer (XRF; Data Set S1). ${ }^{1}$ Selected basalts to basaltic andesites were further analyzed by ICP-MS for trace elements and $\mathrm{Sr}, \mathrm{Nd}, \mathrm{Pb}$, and $\mathrm{Hf}$ isotopes (Table 1). All the samples are plagioclase-rich and pyroxenes are ubiquitous with occasional small olivines contained in basaltic samples. All the samples are fresh and no clay minerals are observed.

\section{Analytical Methods}

[10] Lava samples were broken into small chips a few millimeters in diameter using an iron pestle and soaked in distilled water at $\sim 60^{\circ} \mathrm{C}$ on a hot plate overnight. Supernatant water was exchanged and the same procedure repeated seven times. The rinsed chips were oven dried at $110^{\circ} \mathrm{C}$ overnight and pulverized by an agate mortar for $30 \mathrm{~min}$. Powdered samples were heated at $1000^{\circ} \mathrm{C}$ for $2 \mathrm{~h}$ and fused with alkali fluxes to form low-dilution factor (sample: flux ratio of 1:2) glass discs. The glass discs were analyzed with a RIX 2000 XRF spectrometer (Rigaku) at Shimane University, Japan for 10 major elements and $\mathrm{Ba}, \mathrm{Cr}, \mathrm{Ga}, \mathrm{Ni}, \mathrm{Pb}, \mathrm{Rb}$, Sr, V, Y, and Zr [Kimura and Yamada, 1996] (see Data Set S1).

[11] Sample powders of $0.1000 \mathrm{~g}$ were digested in $\mathrm{HF}-\mathrm{HClO}_{4}$ in tightly sealed Teflon ${ }^{\circledR}$ jars overnight and evaporated to dryness. The dried samples were redigested with a mixed acid and diluted 1000x to $100 \mathrm{~g}$ stock solutions. The stock solutions were further diluted to 50000x and used for a standard

\footnotetext{
${ }^{1}$ Auxiliary material data sets are available at ftp://ftp.agu.org/ apend/gc/2010gc003050. Other auxiliary material files are in the HTML.
}

addition method ICP-MS analyses using a modified VG-PQ3 (Thermo Fisher Scientific) quadrupole ICP-MS at Shimane University [Kimura and Yoshida, 2006; Kimura et al., 1995]. Standard basalt JB-2 (Izu-Oshima Miharayama basalt lava provided by the Geological Society of Japan) was also analyzed. Analytical results and comparison of our result is listed in Table 1.

[12] Sr and Nd were separated using a conventional cation resin separation for Sr and REE [Iizumi et al., 1994, 1995]. Nd was further separated from REE separates using HDEHP columns [Richard et al., 1976]. Separated $\mathrm{Sr}$ and Nd were analyzed with a Finnigan MAT262 (Thermo Fisher Scientific) thermal ionization mass spectrometer (TIMS) at Shimane University [Iizumi et al., 1994, 1995]. Pb was separated by single step miniature anion exchange columns and analyzed using a VG Plasma 54 (Thermo Fisher Scientific) multicollector ICP-MS (MC-ICP-MS) at Shimane University [Kimura et al., 2006]. Hf was separated by a two-step column method [Blichert-Toft et al., 1997] and analyzed with the same MC-ICP-MS. Standard materials of NIST SRM987 (Sr), La Jolla (Nd), JB-1a (Hf) and JB-2 $(\mathrm{Pb})$ were also analyzed and the results listed in Table 1. All data for the standard samples agree well with reported values for these isotopic standards [Hanyu et al., 2005; Iizumi et al., 1994, 1995; Ishizuka et al., 2003] (see Table 1).

\section{Geochemical Variations of N-Izu Quaternary Lavas}

\subsection{Major Elements}

[13] Our major element XRF analytical results are similar to those reported previously (Figure 2). Almost all the N-Izu lavas plot as subalkali basalt suite on the total alkalis versus silica diagram (Figure 2), although two Udonejima basalt samples lie on the subalkaline and alkaline boundary [LeMaitre et al., 1989]. The Izu-Oshima samples are extremely low in total alkalis but some Toshima samples plot closer to the Izu-Oshima field. Major element composition of the Izu-Oshima lavas is identical with those from N-Izu volcanic front [Ishizuka et al., 2006]. Apart from some exceptions, total alkali contents tend to increase from Izu-Oshima to Toshima, Udonejima and Niijima corresponding to the increasing depth of the WadatiBenioff zone (120-180 km). The difference between RA basalts is subtle, and the data cluster into VF (Izu-Oshima) and RA (Toshima, Udonejima, and Niijima) fields (Figure 2). 


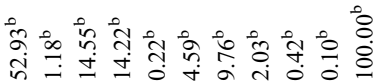

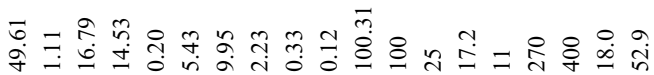

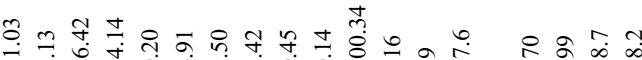

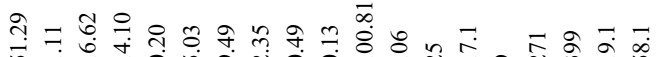

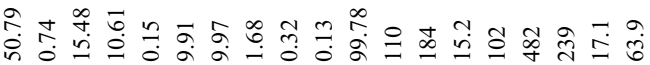

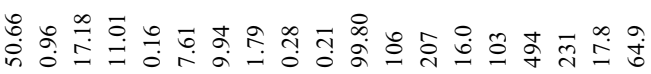

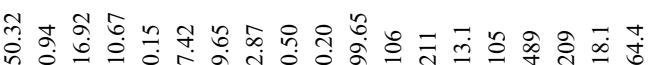

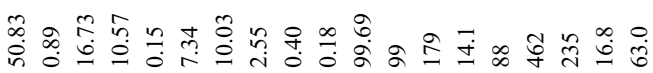

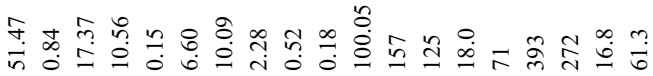

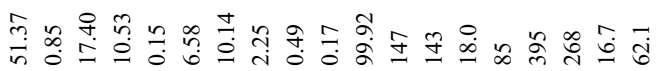

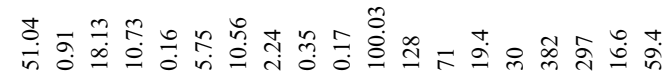

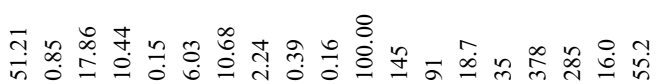

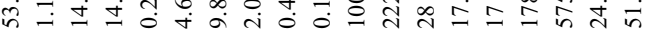

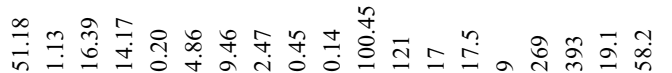

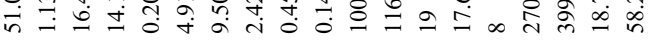

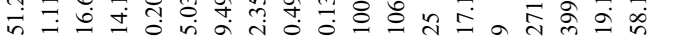

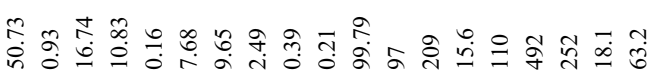

भิ

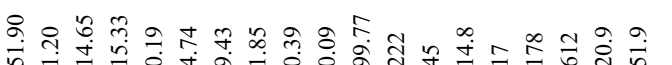
तु

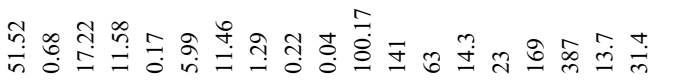

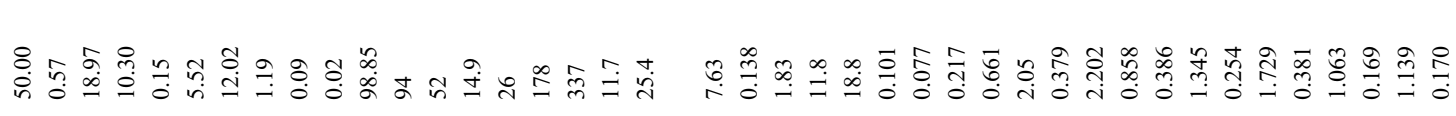
这

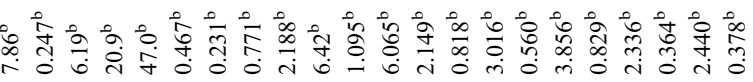

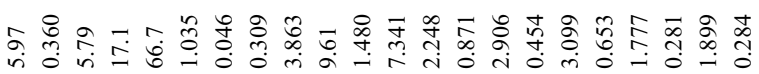

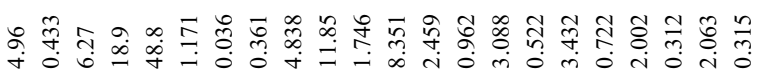

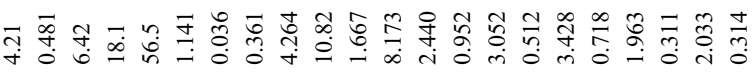

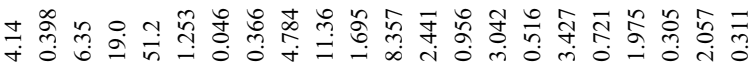

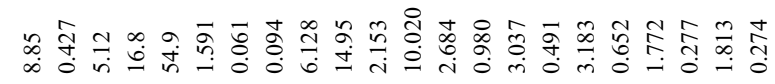

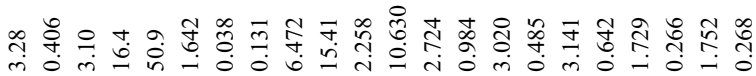

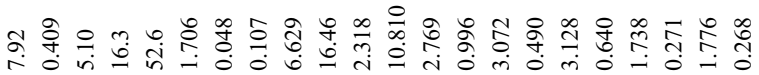

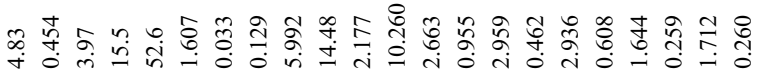

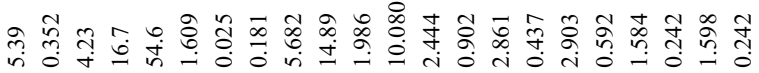

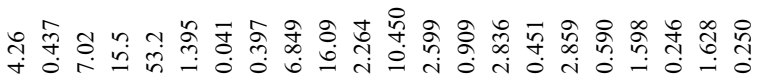

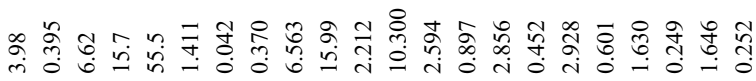

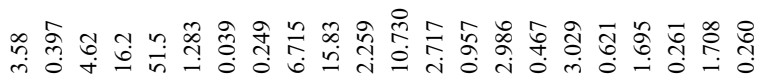

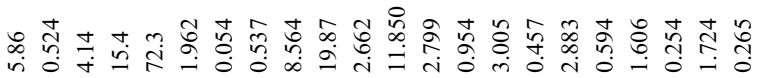

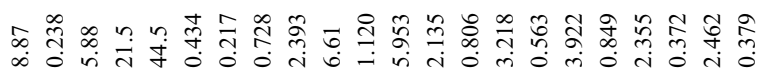

ปั่

t

言

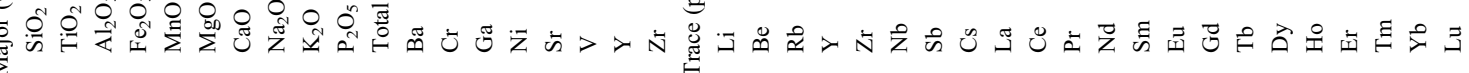




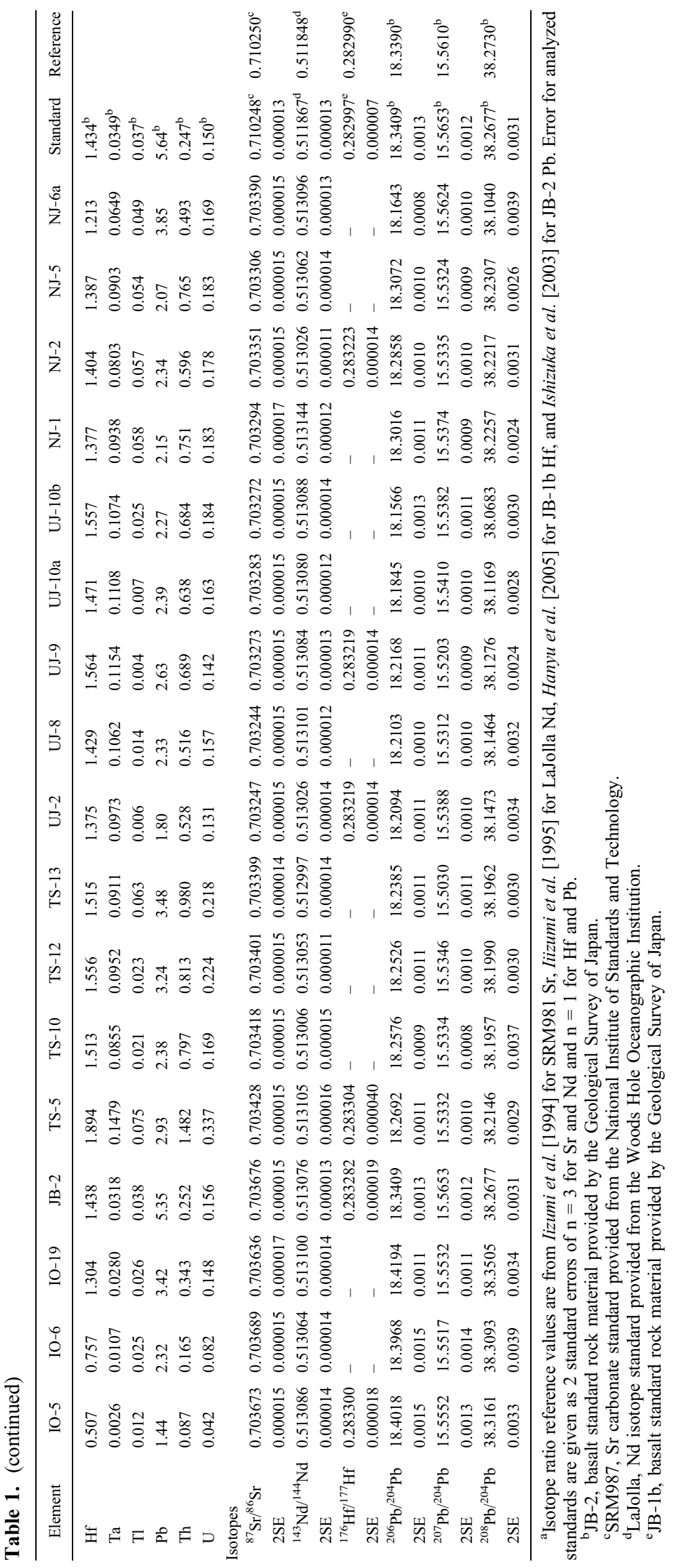



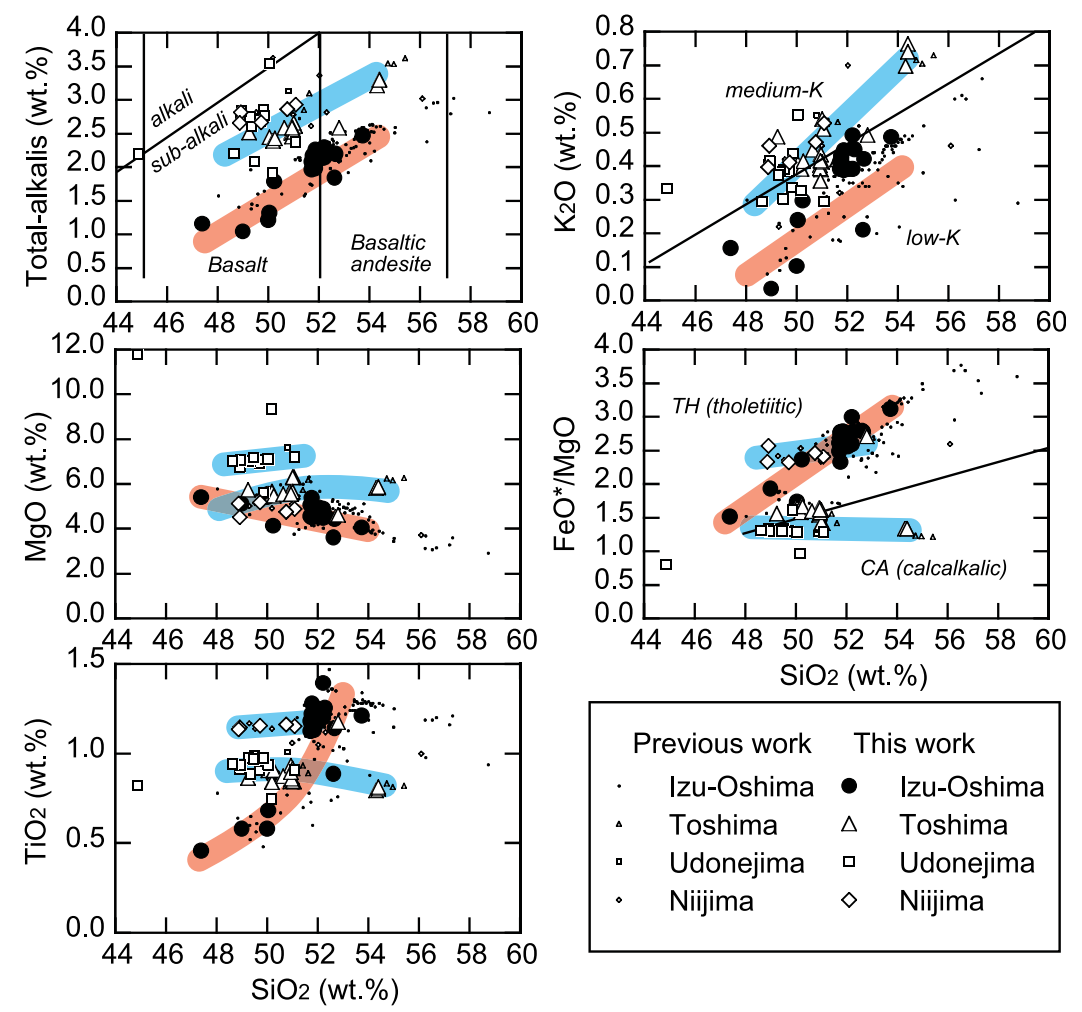

Figure 2. Major element compositions of N-Izu basalt to basaltic andesite lavas. Thick red line, volcanic front trend; thick blue line, rear-arc trends. Discrimination lines are from LeMaitre et al. [1989] for the total alkalis-silica (TAS) diagram, Peccerillo and Taylor [1976] for the K-silica diagram, and Miyashiro [1974] for the $\mathrm{FeO} / \mathrm{MgO}$-silica diagram.

[14] A similar pattern is evident from the $\mathrm{K}_{2} \mathrm{O}$ versus silica diagram. Izu-Oshima lavas are distinctively low in $\mathrm{K}_{2} \mathrm{O}$, and all samples but one plot in the low-K field [Peccerillo and Taylor, 1976]. In contrast, the RA lavas plot around the low-K and medium-K discrimination line or in the medium-K field.

[15] The $\mathrm{MgO}$ contents of the lavas range from 3.8 to $9.5 \mathrm{wt} \%$ with relatively high $\mathrm{MgO}$ in RA lavas at given silica content (Figure 2). Because of the presence of a small number of secondary veins, we believe that one low-silica lava sample with high $\mathrm{MgO}(\sim 12 \mathrm{wt} \%)$ from Udonejima appears to be affected by alteration (although obvious veins were removed prior to analysis). The sample has been eliminated from further discussion.

[16] The $\mathrm{FeO} / \mathrm{MgO}$ diagram reveals that all $\mathrm{Izu}^{-}$ Oshima and Niijima lavas have tholeiitic affinities, whereas the Udonejima and Toshima lavas are calc-alkalic. Although the Niijima lava is rich in $\mathrm{FeO}^{*}$, the $\mathrm{FeO}^{*} / \mathrm{MgO}$ ratio is constant suggesting an atypical tholeiitic trend. The $\mathrm{TiO}_{2}$ contents of the lavas increase with increasing silica for IzuOshima tholeiitic lavas, whereas no increases are shown by the RA lava suites (Figure 2). The Niijima lavas again do not behave like typical tholeiites, which show $\mathrm{TiO}_{2}$-silica covariation but instead, have their highest $\mathrm{TiO}_{2}$ content in lavas with the lowest silica content. The $\mathrm{TiO}_{2}$ contents of the most mafic lavas increase from Izu-Oshima through Toshima and Udonejima to Niijima, similar to the variations in total alkali contents. This indicates that Izu-Oshima lavas derive from primitive magmas resulting from either higher degrees of melting $(F)$ than RA lavas, and/or that Izu-Oshima lavas are derived from a more depleted mantle source.

\subsection{Trace Elements}

[17] Trace element abundances and variation are shown in normalized multielement plots (Figure 3). The data are from selected less differentiated basalts from each volcanic island together with two basaltic andesites (JB-2 and lava flow near JB-2 sample site) from Izu-Oshima for comparison (Table 1).

[18] The Izu-Oshima VF basalts are extremely low in incompatible element abundances, including $\mathrm{K}_{2} \mathrm{O}, \mathrm{P}_{2} \mathrm{O}_{5}$, and $\mathrm{TiO}_{2}$ (Figure 2), and are also very low in REEs, with extremely depleted LREE and 

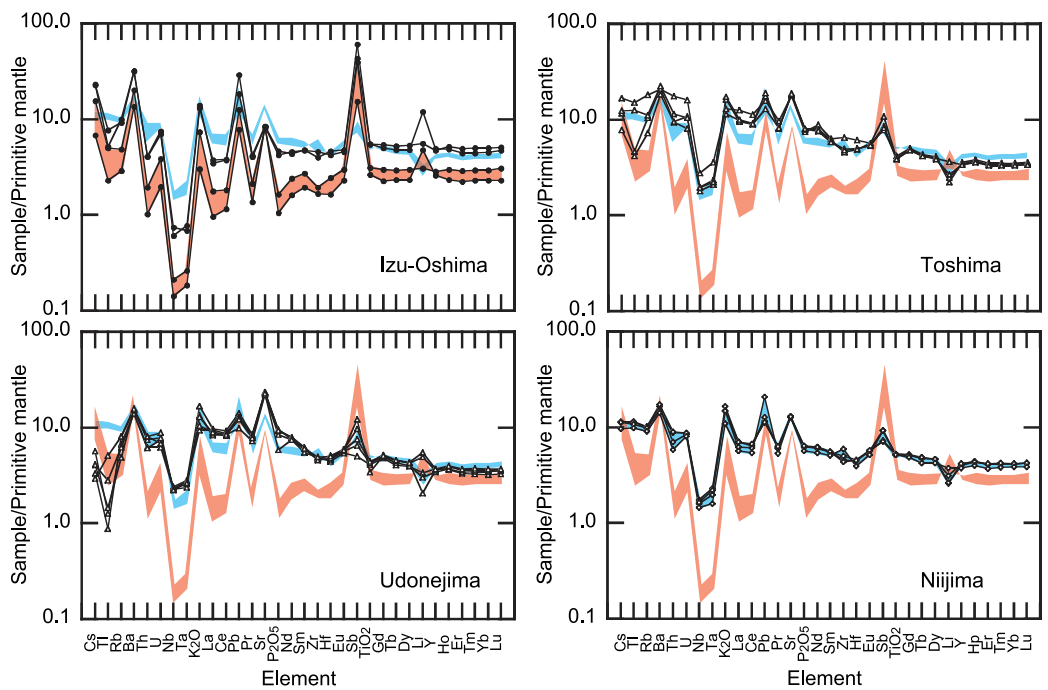

Figure 3. Normalized multielement plot of representative basalt lavas from N-Izu. Normalization values are from Sun and McDonough [1989]. Red and blue shaded areas are references for VF and RA basalts. Two elevated values in Izu-Oshima are from JB-2 andesite and a sample from the same lava flow.

HFSE. Positive spikes are prominent in $\mathrm{Cs}, \mathrm{Ba}, \mathrm{U}$, $\mathrm{Pb}, \mathrm{Sr}$, and $\mathrm{Sb}$. Li also shows a slight positive anomaly. The behavior of the REE and the trace HFS elements is similar to that of the major HFS elements $\left(\mathrm{TiO}_{2}\right.$ and $\left.\mathrm{P}_{2} \mathrm{O}_{5}\right)$. These characteristics are ubiquitous in the late Cenozoic VF lavas from elsewhere along the Izu arc [Ishizuka et al., 2006; Tamura et al., 2007].

[19] In contrast to VF basalts, the RA basalts are relatively enriched in incompatible elements. RA basalts show elevated REE with fractionated LREE and HFSE, with the HFSEs strongly depleted relative to LREE and LILEs. Some samples have Cs and $\mathrm{Tl}$ abundances identical to those in VF basalts [Tamura et al., 2007]. Positive spikes in $\mathrm{Ba}, \mathrm{K}_{2} \mathrm{O}$, $\mathrm{Pb}, \mathrm{Sr}$, and $\mathrm{Sb}$ are all similar between $\mathrm{RA}$ and $\mathrm{VF}$ lavas; however, the increased concentrations of these elements are less prominent in RA lavas than in VF lavas. Although depletions in $\mathrm{Tl}$ and $\mathrm{Rb}$ are evident in some Toshima and all Udonejima basalts, other incompatible element characteristics are similar between Toshima, Udonejima, and Niijima basalts. Thus, although there are some internal variations within RA and VF lavas, the differences between these two groups are consistently much more significant. In the following discussion the $\mathrm{N}$-Izu basalts are classified into VF and RA groups as a basis for comparison.

\subsection{Incompatible Trace Element Behavior}

[20] Incompatible trace element ratios are useful in characterizing the sources that contribute to basaltic magmas. In subduction zone settings, $\mathrm{Ba} / \mathrm{Th}$ and $\mathrm{Pb} / \mathrm{Ce}$ are believed to be indicators of slab-derived fluid addition to the mantle peridotite basalt source because $\mathrm{Ba}$ and $\mathrm{Pb}$ are more fluid mobile whereas $\mathrm{Th}$ and $\mathrm{Ce}$ are relatively compatible in melts but not in hydrous fluids [Pearce et al., 2005; Peate et al., 1997]. Sb behaves similarly to $\mathrm{Ba}$ and $\mathrm{Pb}$ during slab dehydration [Bebout et al., 1999], such that $\mathrm{Sb} / \mathrm{Gd}$ is also useful. Figure 4 plots $[\mathrm{Ba} / \mathrm{Th}] \mathrm{n}$ versus $[\mathrm{Pb} / \mathrm{Ce}] \mathrm{n}$ and $[\mathrm{Sb} / \mathrm{Gd}] \mathrm{n}$ versus $[\mathrm{Pb} / \mathrm{Ce}] \mathrm{n}([\mathrm{X} /$ $\mathrm{Y}] \mathrm{n}$ indicates primitive mantle normalized element ratios where $[\mathrm{X} / \mathrm{Y}] \mathrm{n}=1$ using the primitive mantle (PM) estimate of Sun and McDonough [1989]). In both plots, the RA basalts plot close to PM but still have somewhat elevated $\mathrm{Ba} / \mathrm{Th}, \mathrm{Pb} / \mathrm{Ce}$ and $\mathrm{Sb} / \mathrm{Gd}$. In contrast, the VF basalts have very high ratios suggesting significant slab fluid addition.

[21] The $[\mathrm{Nb} / \mathrm{Yb}] \mathrm{n},[\mathrm{La} / \mathrm{Yb}] \mathrm{n}$, and $[\mathrm{Nb} / \mathrm{Zr}] \mathrm{n}$ ratios record differences in the amount of source depletion, degree of mantle melting and/or the contribution of residual garnet in the basalt source mantle [Pearce et al., 2005; Peate et al., 1997]. [Nb/Yb]n and $[\mathrm{Nb} / \mathrm{Zr}] \mathrm{n}$ are significantly lower than unity, indicating strong depletion in incompatible HFSE in the mantle source compared to PM. In contrast, $[\mathrm{La} / \mathrm{Yb}] \mathrm{n}$ is less than unity in the VF but greater than unity in the RA. There are near-linear correlations between $[\mathrm{La} / \mathrm{Yb}] \mathrm{n}$ and other HFS element ratios increasing in the order of VF, Niijima, and Udonejima and Toshima in the RA. This correlation and trend might be achieved by different degrees of partial melting of compositionally similar 

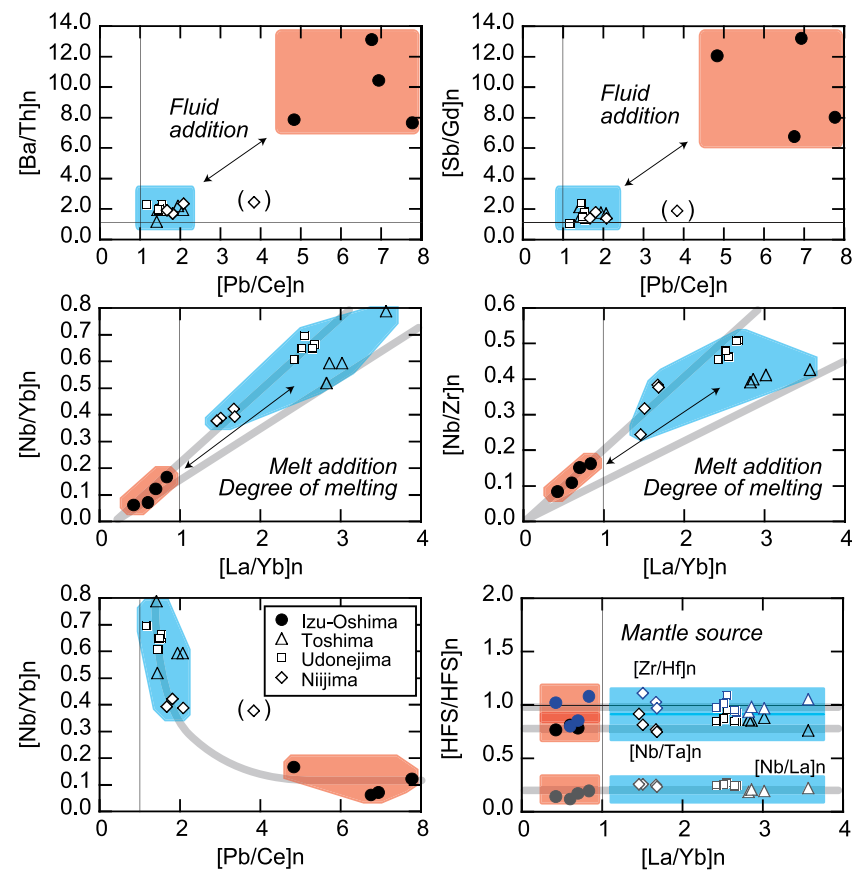

Figure 4. Incompatible trace element ratios of basalt lavas from the N-Izu arc. Trace element concentrations are normalized to primitive mantle values [Sun and McDonough, 1989]. An outlier from Niijima basalts is bracketed. Red and blue fields are for VF and RA basalts. Thin lines are primitive mantle ratios. Note that $\mathrm{PM}$ values for $\mathrm{Nb} / \mathrm{Zr}$ and $\mathrm{NbYb}$ are unity and off scale.

sources or by mixing between low $\mathrm{La} / \mathrm{Nb}$ and high $\mathrm{La} / \mathrm{Nb}$ melts.

[22] A comparison between HFSE ratios and trace element indices that are sensitive to fluid inputs (e.g., $[\mathrm{Nb} / \mathrm{Yb}] \mathrm{n}$ versus $[\mathrm{Pb} / \mathrm{Ce}] \mathrm{n}$ ) also suggests a continuum between VF and RA processes with the results fitting a hyperbolic trend (Figure 4). This relation may be produced by fluid addition from the slab to the VF basalt source (increasing $\mathrm{Pb} / \mathrm{Ce}$ ), whereas melt addition occurs within the RA basalt source, as suggested by previous workers [Ishizuka et al., 2006; Tamura et al., 2007; Tollstrup et al., 2010; Turner et al., 1997].

[23] Finally, unlike other incompatible element ratios, the HFSE ratios ([Zr/Hf]n, $[\mathrm{Nb} / \mathrm{Ta}] \mathrm{n},[\mathrm{Nb} / \mathrm{La}] \mathrm{n})$ versus $[\mathrm{La} / \mathrm{Yb}] n$ show no consistent change across the rear arc although $[\mathrm{La} / \mathrm{Yb}] \mathrm{n}$ shows considerable change (Figure 4). This may indicate a similar mantle source composition beneath RA and VF, coupled with differences in the degree of partial melting (greater for VF and less for RA). If slab melt addition is the cause elevated $[\mathrm{Nb} / \mathrm{Yb}] \mathrm{n}$ in the RA basalts, the HFSE ratios probably cannot remain unchanged as these ratios would differ between AOC, SED, and PM [Green, 1995]. We evaluate this problem further in sections 5.2.6 and 5.4.1.

\subsection{Isotopic Variations}

[24] There are also distinct differences between the VF and RA lavas in terms of their radiogenic isotope compositions (Figure 5). In general Izu VF basalts typically show more radiogenic ${ }^{87} \mathrm{Sr} /{ }^{86} \mathrm{Sr}$ than in RA basalts [Hochstaedter et al., 2001; Ishizuka et al., 2003, 2006; Taylor and Nesbitt, 1998; Tollstrup et al., 2010]. The same is true in the N-Izu (Figure 5), where the Izu-Oshima VF lavas have elevated ${ }^{87} \mathrm{Sr} /{ }^{86} \mathrm{Sr}$ at a given ${ }^{143} \mathrm{Nd} /{ }^{144} \mathrm{Nd}$ compared to RA basalts. However, the subparallel fields, defined by the VF and RA basalts, are less prominent in our study area than in other parts of the $\mathrm{N}-\mathrm{Izu}$ arc, even though the N-Izu VF basalt field almost exactly overlaps that of other Izu VF basalts [Ishizuka et al., 2006; Tamura et al., 2007]. In detail, the N-Izu RA basalts also have a slightly enriched $\mathrm{Sr}$ isotopic composition compared to other Izu RA basalts and define a field intermediate between VF and RA basalts.

[25] The $\mathrm{Pb}$ isotopic results show similar features to those evident from $\mathrm{Sr}$, with more radiogenic $\mathrm{Pb}$ isotopic compositions found in VF basalts relative to those in RA basalt. Overall, the Izu and N-Izu basalts plot on a narrow linear array suggesting near binary mixing of $\mathrm{Pb}$ isotope components. Elevated fluid mobile element concentrations (including $\mathrm{Pb}$ 

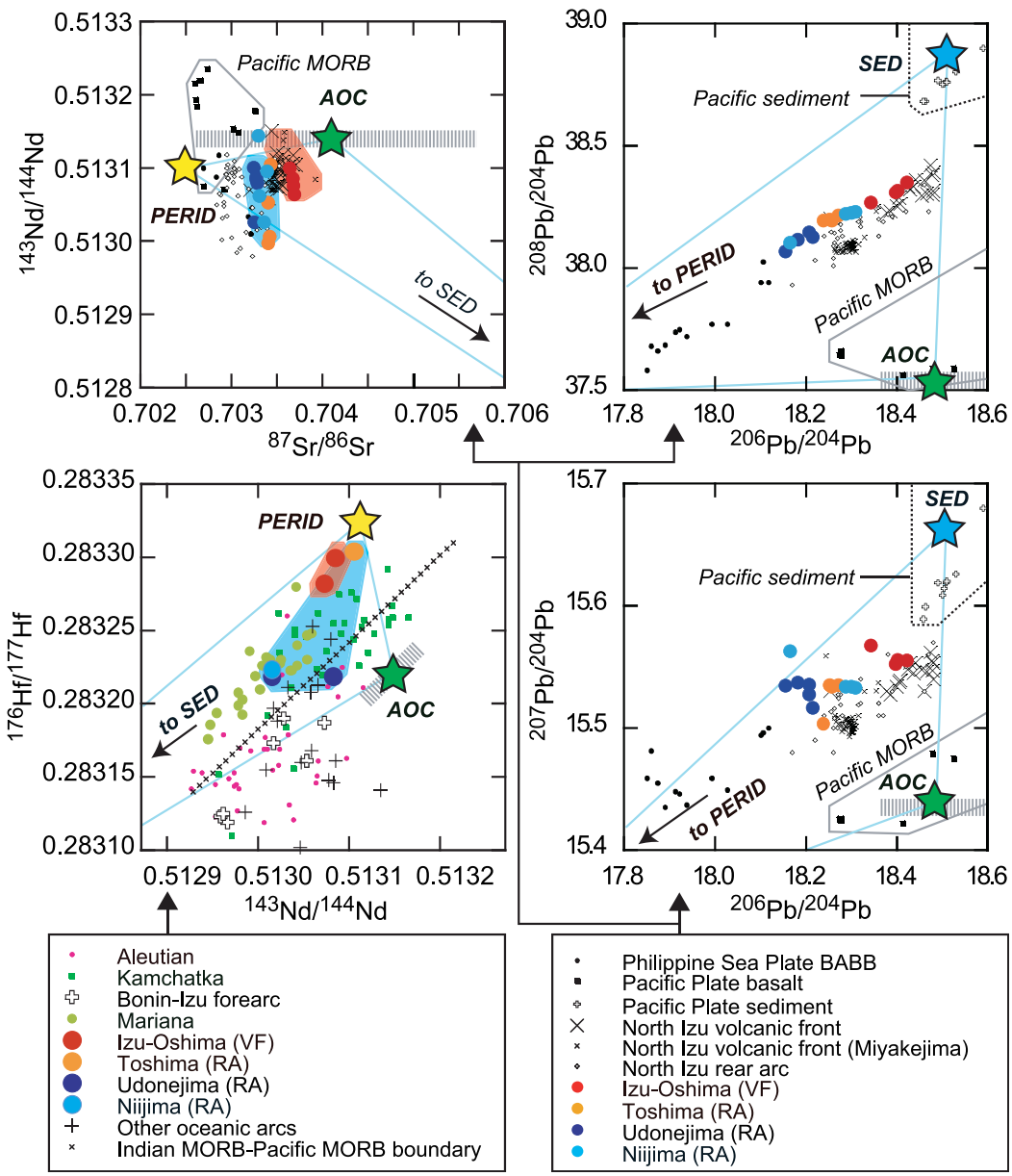

Figure 5. $\mathrm{Sr}-\mathrm{Nd}, \mathrm{Pb}-\mathrm{Pb}$, and $\mathrm{Nd}-\mathrm{Hf}$ isotope plots of basalt lavas from $\mathrm{N}-\mathrm{Izu}$. Thick dotted gray line, isotopic variation of the Pacific MORB (Geochemistry of rocks of the oceanic and the continents (GEOROC), Max-Planck-Institut für Chemie, http://georoc.mpch-mainz.gwdg.de/georoc/). Stars are from the isotopic ratios used for ABS3 calculations as shown in Table 2. Thin blue lines connect sediment (SED), altered oceanic crust (AOC), and peridotite (PERID) source components.

and Sr) in VF basalts are consistent with the inferred strong slab fluid contribution to the N-Izu VF basalts, because these should carry radiogenic $\mathrm{Pb}$ and $\mathrm{Sr}$ [Hochstaedter et al., 2001; Ishizuka et al., 2003, 2006; Taylor and Nesbitt, 1998; Tollstrup et al., 2010]. The linear $\mathrm{Pb}$ isotope relationship extends to the back arc Shikoku Basin basalt (Philippine Sea plate BABB in Figure 5), suggesting slab flux addition to a mantle source that is compositionally restricted. It is interesting that the Izu arc basalts have such uniform $\mathrm{Pb}$ isotopic compositions over a $1000 \mathrm{~km}$ range, considering that the age of the subducting Pacific Plate changes significantly over this distance (120-150 Ma).

[26] For Nd isotopes, along-arc variation of the mantle source has been suggested [Hochstaedter et al., 2001; Ishizuka et al., 2003, 2006; Taylor and Nesbitt, 1998]; however, increasing data from the Izu-Bonin arc gave rise to the suggestion that these variations relate to local variety of the mantle source [Tollstrup et al., 2010]. To investigate mantle heterogeneity across the arc, we examined Nd-Hf isotopic compositions. Except for one Udonejima sample, all analyzed samples fall in the Indian MORB mantle domain [Woodhead et al., 2001] forming a trend that is slightly oblique to the Indian MORB and Pacific MORB mantle domain boundary. This is consistent with what is seen for $\mathrm{Pb}$ isotopic compositions, which also plot in the field for Indian Ocean basalts. The N-Izu Nd-Hf trend overlaps with the field of Mariana arc basalts rather than Bonin-Izu fore arc (Figure 5). This strongly suggests that the mantle wedge beneath the N-Izu largely has Indian MORB-like mantle affinities, with some heterogeneity (as shown by the Udonejima sample). The VF lavas are the most radiogenic, whereas RA basalts scatter considerably. The larger 
Hf isotope variation in Mariana arc lavas has been interpreted as being due to contributions from slab melt to the mantle source [Tollstrup and Gill, 2005] and for RA in the southern Izu arc from "supercritical melt" [Tollstrup et al., 2010]. The latter would explain the larger Hf-Nd isotopic variations seen in N-Izu RA basalts. However, as changes in element abundances and isotope ratios for $\mathrm{Nd}$ and Hf are subtle, more data are required to address this for N-Izu, and this is beyond the scope of this paper.

\section{Origin of the Across Arc Chemical Variations}

\subsection{Arc Basalt Simulator Version 3 Model}

[27] Kimura et al. [2009] developed a quantitative forward mass balance model for studying arc basalt genesis that explicitly addresses (1) slab dehydration during prograde metamorphism in the subducting plate, (2) fluid-mantle reaction at the base of the mantle wedge and in the high-temperature asthenospheric mantle wedge, and (3) $\mathrm{P}-\mathrm{T}-\mathrm{XH}_{2} \mathrm{O}$ parameterized fluid-fluxed mantle melting. Arc Basalt Simulator version 2 (ABS2) is an Excel spreadsheet based forward model of coupled slab dehydrationfluid fluxed mantle melting [Kimura et al., 2009]. The model allows the user to input three source compositions: (1) subducted sediment (SED), (2) altered oceanic crust (AOC), and (3) choice of variously depleted MORB mantle (PERID). However, in order to study the origin of the N-Izu basalts, slab melting and melt-fluxed mantle melting processes need to be simulated together with the slab dehydration and fluid-fluxed melting functions already available with ABS2. We have modified the ABS2 and developed ABS3 for these purposes.

[28] Briefly, the ABS3 model includes new features that simulate slab melting and melt fluxed mantle melting (see Figure 1 in Text S1). The slab melting is based on incorporation of the available experimental data for AOC and SED at slab conditions between 0 and $6 \mathrm{GPa}$, and these data are incorporated into petrogenetic phase diagrams of slab AOC and SED (see Figure 2 in Text S1). For the appropriate slab melting conditions, melt compositions are calculated using the degree of melting and residual mineralogy of the slab SED/AOC. The $\mathrm{H}_{2} \mathrm{O}$ content in the slab melts is calculated based on modes of consumed hydrous silicate minerals.

[29] Melt fluxed mantle melting is then simulated based on pMELTS calculations of mantle compo- sitions variously modified by addition of the slab melt by up to $30 \mathrm{wt} \%$. The effect of $\mathrm{H}_{2} \mathrm{O}$ on melting is based on the formulation of Katz et al. [2003] assuming that $\mathrm{H}_{2} \mathrm{O}$ in the slab melt controls the degree of melting of the fluxed mantle (see Text S1).

[30] Because of the limited availability of experimental data sets for carbonaceous, chert, and pelagic sediments, the SED component used in ABS3 is limited to a bulk sediment rather than distinct treatment on the various sediment components as done in ABS2. The ABS3 slab SED petrogenetic model for both subsolidus and supersolidus is calculated and formulated for the terrigeneous sediment composition studied by Hacker [2008]. This composition is close to that of the average upper continental crust composition [Taylor and McLennan, 1985]. At present this limitation is unavoidable due to the limited experimental results available for various SED components at wide P-T range. Slab dehydration and fluid-fluxed mantle melting modes are otherwise completely identical to the ABS2 model.

[31] Full details of the modification and calculation scheme of ABS3 are given in Text S1. A program code built on a Microsoft based Excel spreadsheet is available by downloading Software S1. Readers should also refer to Kimura et al. [2009] for the concept of ABS2, which is similar in many respects to $\mathrm{ABS} 3$. The advantages of the ABS3 model are its fully integrated petrologic treatment of slab fluid dehydration, slab melting, and fluid/melt-fluxed mantle melting with fully consistent incompatible element mass balance including isotope systems. An automated fitting function allows the best fit conditions to be found, including intensive and extensive parameters of slab-mantle processes (see Text S1 and Software S1 and discussions below).

\subsection{ABS3 Examination of N-Izu Basalts}

[32] In the following we describe the practical application of ABS3 to the N-Izu basalts.

\subsubsection{Primary Arc Basalt Compositions}

[33] An important constraint for ABS3 calculations is the primary arc basalt composition. The incompatible trace element abundances in the primary basalt can be estimated by various schemes. One example is an olivine maximum fractionation model, whereby equilibrium olivine is added until the basalt composition is in equilibrium with mantle peridotite [Takahashi, 1986]. Kimura et al. [2006] and Machida et al. [2008] have applied this method by 
Table 2. Primitive Basalt Compositions of Izu-Oshima, Toshima, and Niijima and Subducted Sediment, AOC Compositions, and Mantle Peridotite Compositions Used for ABS3 Calculations ${ }^{\mathrm{a}}$

\begin{tabular}{|c|c|c|c|c|c|c|}
\hline Element & Izu-Oshima & Toshima & Niijima & $\mathrm{X}(\mathrm{AOC})$ & $\mathrm{X}(\mathrm{SED})$ & X(PERID) \\
\hline $\mathrm{Rb}$ & 1.47 & 3.40 & 4.63 & 20.0 & 25.1 & 0.018 \\
\hline $\mathrm{Ba}$ & 75.5 & 118 & 79.7 & 15.6 & 244 & 0.203 \\
\hline Th & 0.070 & 0.948 & 0.394 & 0.173 & 8.00 & 0.0026 \\
\hline $\mathrm{U}$ & 0.033 & 0.215 & 0.135 & 0.390 & 1.19 & 0.0010 \\
\hline $\mathrm{Nb}$ & 0.081 & 1.26 & 0.828 & 2.89 & 3.87 & 0.057 \\
\hline $\mathrm{Ta}$ & 0.0062 & 0.095 & 0.052 & 0.210 & 0.239 & 0.0039 \\
\hline K & 604 & 2051 & 2185 & 5147 & 7286 & 30.5 \\
\hline $\mathrm{La}$ & 0.529 & 5.48 & 3.09 & 3.40 & 27.3 & 0.087 \\
\hline $\mathrm{Ce}$ & 1.64 & 12.7 & 7.69 & 11.4 & 31.3 & 0.303 \\
\hline $\mathrm{Pb}$ & 1.15 & 0.960 & 0.670 & 0.430 & 6.82 & 0.011 \\
\hline $\operatorname{Pr}$ & 0.303 & 1.51 & 0.980 & 2.06 & 5.37 & 0.068 \\
\hline $\mathrm{Sr}$ & 142 & 242 & 216 & 110 & 161 & 5.17 \\
\hline $\mathrm{Nd}$ & 1.76 & 7.58 & 5.87 & 11.3 & 28.7 & 0.417 \\
\hline $\mathrm{Sm}$ & 0.686 & 1.79 & 1.80 & 3.95 & 6.35 & 0.184 \\
\hline $\mathrm{Zr}$ & 15.0 & 46.3 & 35.8 & 112 & 48.1 & 4.22 \\
\hline $\mathrm{Hf}$ & 0.405 & 1.21 & 0.970 & 3.07 & 0.878 & 0.134 \\
\hline $\mathrm{Eu}$ & 0.309 & 0.610 & 0.697 & 1.34 & 1.46 & 0.079 \\
\hline $\mathrm{Gd}$ & 1.08 & 1.92 & 2.32 & 5.55 & 5.46 & 0.301 \\
\hline $\mathrm{Tb}$ & 0.203 & 0.292 & 0.363 & 1.01 & 0.880 & 0.060 \\
\hline Dy & 1.38 & 1.85 & 2.48 & 6.56 & 5.26 & 0.441 \\
\hline $\mathrm{Y}$ & 9.42 & 9.88 & 13.7 & 40.7 & 36.8 & 2.78 \\
\hline Ho & 0.305 & 0.380 & 0.523 & 1.43 & 1.10 & 0.100 \\
\hline $\mathrm{Er}$ & 0.850 & 1.03 & 1.42 & 4.09 & 3.15 & 0.306 \\
\hline $\mathrm{Tm}$ & 0.135 & 0.163 & 0.225 & 0.617 & 0.461 & 0.049 \\
\hline $\mathrm{Yb}$ & 0.911 & 1.10 & 1.52 & 4.02 & 2.90 & 0.331 \\
\hline $\mathrm{Lu}$ & 0.136 & 0.169 & 0.227 & 0.636 & 0.415 & 0.052 \\
\hline \multicolumn{7}{|l|}{ Isotopes } \\
\hline${ }^{87} \mathrm{Sr} /{ }^{86} \mathrm{Sr}$ & 0.70367 & 0.70343 & 0.70339 & 0.70400 & 0.71055 & 0.70240 \\
\hline${ }^{143} \mathrm{Nd} /{ }^{144} \mathrm{Nd}$ & 0.51309 & 0.51310 & 0.51310 & 0.51310 & 0.51235 & 0.51310 \\
\hline${ }^{206} \mathrm{~Pb} /{ }^{204} \mathrm{~Pb}$ & 18.401 & 18.271 & 18.165 & 18.400 & 18.450 & 17.500 \\
\hline${ }^{207} \mathrm{~Pb} /{ }^{204} \mathrm{~Pb}$ & 15.556 & 15.535 & 15.563 & 15.430 & 15.683 & 15.300 \\
\hline${ }^{208} \mathrm{~Pb} /{ }^{204} \mathrm{~Pb}$ & 38.316 & 38.215 & 38.104 & 37.600 & 38.955 & 37.600 \\
\hline
\end{tabular}

${ }^{\mathrm{a}}$ Unit is ppm.

monitoring $\mathrm{Ni}$ and $\mathrm{Mg} \#$ in olivine in the basalt until this approach yielded a melt in equilibrium with mantle olivine [Takahashi, 1986]. The same approach is applied to the most $\mathrm{MgO}$-rich basalts $(\mathrm{MgO}>6 \mathrm{wt} \%)$ from this study in order to minimize the effect of fractionation of plagioclase and clinopyroxenes, which are not directly accounted for by this correction. The estimated primitive basalt compositions are shown in Table 2. We also compared the calculation using the scheme of Lee et al. [2009]. Our estimates on the primary magma compositions are almost identical with the estimates by the Lee et al. [2009] olivine maximum fractionation model with $\mathrm{H}_{2} \mathrm{O}$ content in the primary magmas that range between 3 and $6 \mathrm{wt} \%$ and with mantle olivine having $\mathrm{Mg} \#=91$.

\subsubsection{Source Material Compositions}

[34] Subducting SED and AOC and wedge mantle compositions are required inputs for the ABS3 forward model. SED and AOC compositions for N-Izu subduction zone are available from ODP Site 1149 drill cores [Hauff et al., 2003; Kelley et al., 2003; Plank et al., 2007; Plank and Langmuir, 1998] and are given in Table 2.

[35] The AOC/SED trace element and $\mathrm{Sr}-\mathrm{Nd}-\mathrm{Pb}$ isotopic data are set in the ABS3 DATA_INPUT worksheet (Software $\mathrm{S} 1$ ). The isotopic composition of the mantle is taken from the Shikoku Basin basalts, whereas trace element composition is based on estimates of DMM (see Table 2). Three possible DMM models [Kimura and Yoshida, 2006; Salters and Stracke, 2004; Workman and Hart, 2005] are provided with ABS3. In this case we use the estimate of Workman and Hart [2005] for N-Izu, because this provided the best fit (see below). The degree of source DMM depletion prior to arc magma genesis can also be examined using a melt depletion parameter \%MORBext (Text S1 and Software S1) [see also Kimura et al., 2009], and is fully discussed in section 5.3.4. 

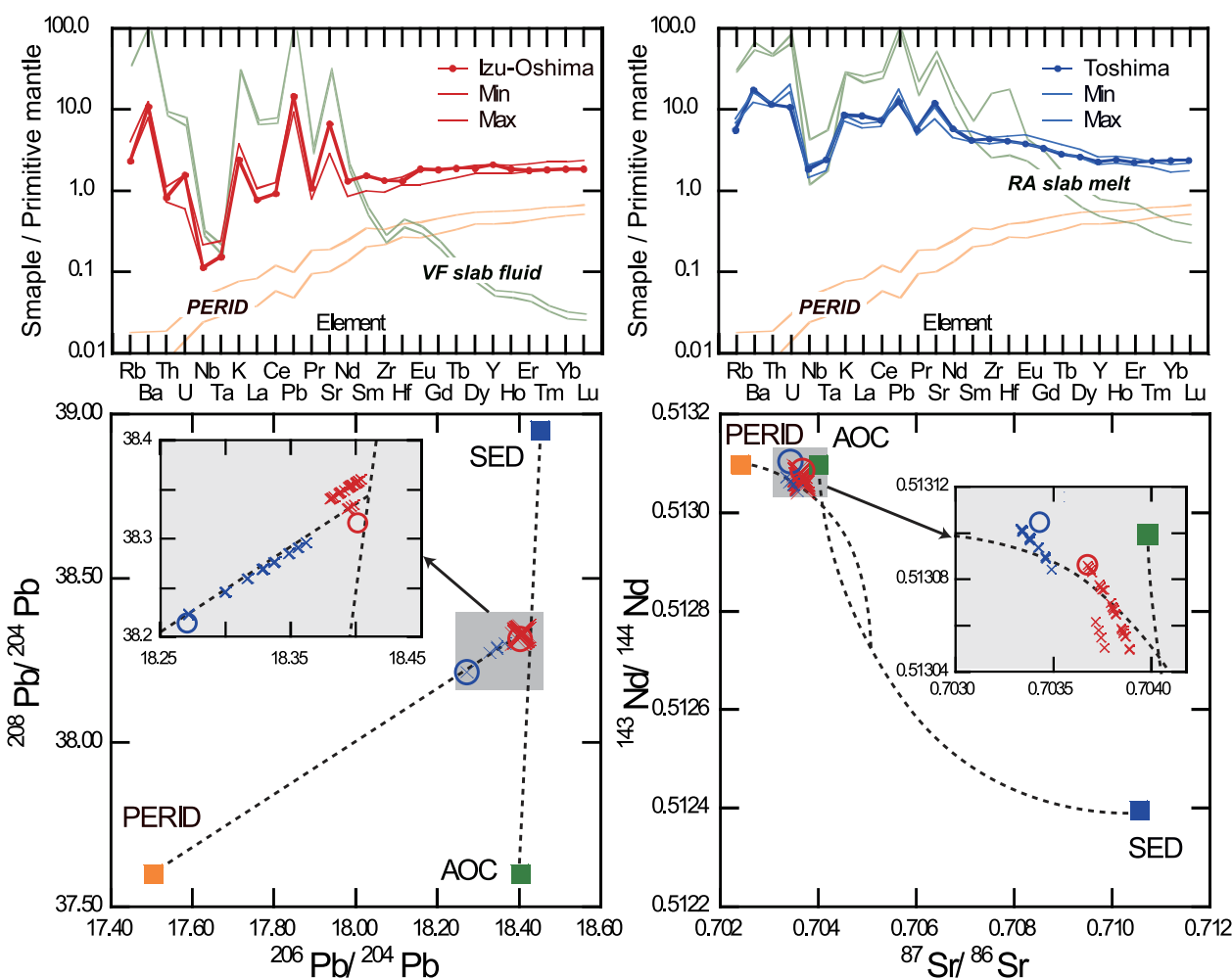

Figure 6. Fitting calculation results from Arc Basalt Simulator version 3 (ABS3) model calculations for Izu-Oshima (VF) and Toshima (RA) cross-chain basalts. (top) Thin lines delimit minimum and maximum values obtained from ABS3 calculations, solid line with circles denotes estimated primary basalt composition, green thin lines denote calculated melt/fluid compositions and their ranges, and thin orange lines denote calculated source PERID compositions and their ranges. (bottom left) $\mathrm{Pb}$ isotope calculation results (crosses) with primary basalt and source compositions (open circles). SED, sediment; PERID, peridotite; AOC, altered oceanic crust. (bottom right) Sr-Nd isotope systematics. Symbols are same as in Figure 6 (bottom left). Insets in Figure 6 (bottom) are close-ups of shaded areas.

\subsubsection{Slab P-T Trajectory}

[36] In addition, a slab P-T path necessary for the slab flux calculations was derived from a geodynamic model calculated specifically for N-Izu [Syracuse et al., 2010]. ABS3 contains estimates of the slab $\mathrm{P}-\mathrm{T}$ path for a number of subduction zones worldwide (Software S1).

\subsubsection{Preliminary Mass Balance Fitting and Automated Fine Adjustment}

[37] Once the various source compositions and slab $\mathrm{P}-\mathrm{T}$ path were set, practical ABS3 analysis begins with manual determination of slab SED-AOC contributions to the slab flux (either fluid or melt) by monitoring mass balance calculation based on both trace element abundances and isotopic compositions $\left({ }^{208} \mathrm{~Pb} /{ }^{204} \mathrm{~Pb}-{ }^{206} \mathrm{~Pb} /{ }^{204} \mathrm{~Pb}\right.$ and ${ }^{87} \mathrm{Sr} /{ }^{86} \mathrm{Sr}-$ ${ }^{143} \mathrm{Nd} /{ }^{144} \mathrm{Nd}$ systematics $) . \mathrm{Pb}$ isotopes typically provide the most powerful tool for this process (see Figure 6). Slab SED liquid fraction in the slab flux (Fliq(SED) see Text S1 and Software S1 for a list of variables) can be determined by altering Fliq(SED) together with a variable corresponding to slab depth (Slab P(GPa)). The slab depth parameter determines at which depth the slab liquid is derived. Slab liquid compositions vary independently for slab SED and AOC along the slab P-T trajectory in ABS3. The amount of SED/AOC flux in the total slab flux is not constrained by the ABS3 model, so that slab depth and SED flux fraction determines where the slab flux is from and how much slab SED/AOC contributes to the flux.

[38] Mantle melting parameters are melting pressure $(\mathrm{P}(\mathrm{GPa}))$, melting temperature $(\mathrm{T}(\mathrm{C}))$, and slab liquid fraction added to the mantle (Fslb liq.\%), all of which are required parameters for melting models [Ozawa and Shimizu, 1995], with petrological parameterization by Katz et al. [2003] and pMELTS melting algorithms [Ghiorso et al., 2002] used for fluid/melt fluxed melting. All of above parameters (Fliq(SED) and Slab P(GPs) for slab flux parameters and $\mathrm{P}(\mathrm{GPa}), \mathrm{T}(\mathrm{C})$, and Fslb liq/\% for mantle melting parameters) are adjusted iteratively. 

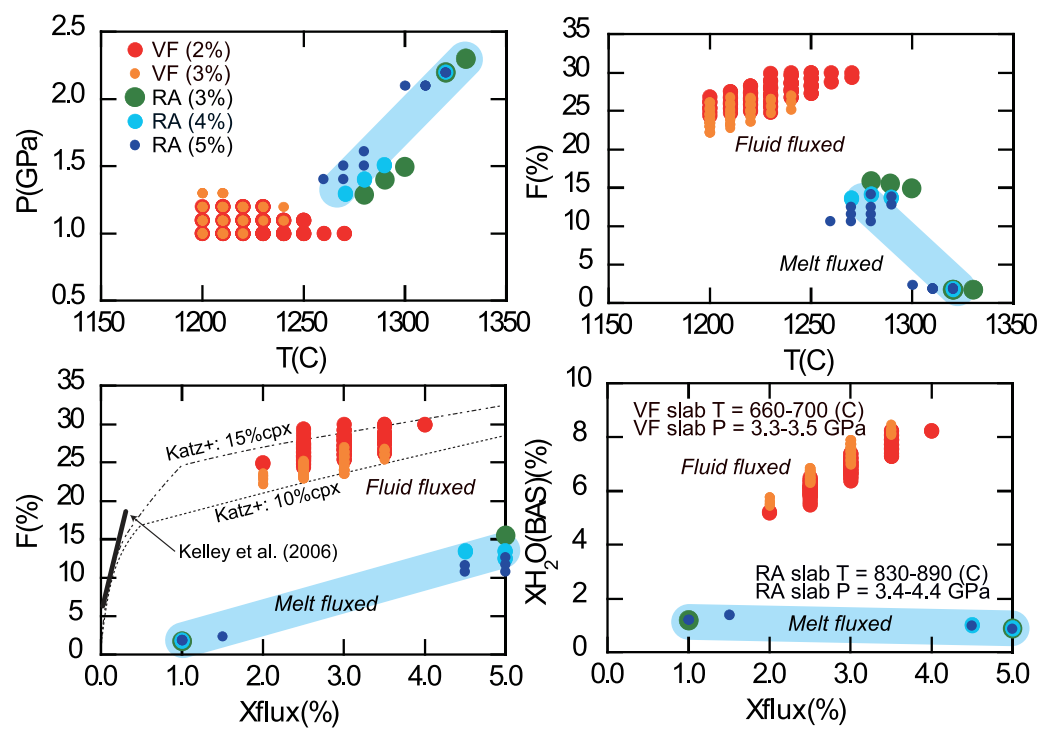

Figure 7. Intensive and extensive variables that reproduce the trace element and isotope compositions of the N-Izu cross-chain basalts. Note that percent values following VF and RA are mantle source depletions relative to the DMM of Workman and Hart [2005]. Thick line on the F(\%)-Xflux(\%) diagram shows the effect of $\mathrm{H}_{2} \mathrm{O}$ on degree of melting from the model of Kelley et al. [2006]. Thin dash-dotted and dotted lines are the calculated results using the Katz et al. [2003] parameterization used in ABS3 for a source mantle with modal cpx 15\% (dash-dotted line) and 10\% (dotted line) and with the assumption that Xflux $(\%)=\mathrm{XH}_{2} \mathrm{O}(\%)=\mathrm{H}_{2} \mathrm{O}_{o}(\mathrm{wt} \%)$ following the definition by Kelley et al. [2006]. The two models show a closer match at low $\mathrm{H}_{2} \mathrm{O}$ fractions up to $0.3 \mathrm{wt} \%$ in the source. However, the effect cannot be extrapolated to higher $\mathrm{H}_{2} \mathrm{O}$ fraction. Melt flux model does not follow the model because $\mathrm{H}_{2} \mathrm{O}$ fractions in the calculated melts are considerably lower $\left(\mathrm{XH}_{2} \mathrm{O}(\%) \ll \mathrm{Xflux}(\%)\right)$ than those in the aqueous fluids.

[39] When a reasonable fit is achieved in terms of both the isotopic and trace element compositions of primary basalts (see Figure 6), this first-order adjustment allows approximation of the entire mass balance. $\mathrm{Sr}$ and $\mathrm{Nd}$ isotope ratios, in many cases, were in good agreement between model and natural basalt when reasonable fits for $\mathrm{Pb}$ isotopes and trace element abundances were achieved (see Figure 6). In the case of $\mathrm{N}$-Izu, the average isotopic composition of ODP1149 SED source [Plank et al., 2007] predicted $\mathrm{Sr}$ and ${ }^{206} \mathrm{~Pb} /{ }^{204} \mathrm{~Pb}$ isotopic compositions in the model basalts that are systematically high, and $\mathrm{Nd}$ isotope ratios low. However, those compositions can be adjusted to provide adequate fits by using SED isotopic compositions that are within the range observed in ODP1149 SED [Plank et al., 2007; Plank and Langmuir, 1998].

[40] Based on this fit, the plausible ranges of the remaining parameters; slab dehydration/melting depth, open system melting pressure and temperature, and fraction of melt/fluid fluxing the mantle source ((Fliq(SED), Slab P(GPs), P (GPa), T (C), and Fslb liq/\%) were explored by automated fitting using the macro function of the ABS3 Excel spreadsheet (Text S1 and Software S1). The source PERID depletion factor (\%MORBext.) was also varied to test for possible source mantle heterogeneity (see details of these calculations by Kimura et al. [2009]).

\subsubsection{Unused Parameters}

[41] Variations in the liquid fraction from the hydrated mantle wedge (Fliq(DMM), see Text S1 and Software $\mathrm{S} 1$ ) and the zone refining reactions between slab fluxes and mantle (n(PERID)) are modeled by ABS3 but did not prove effective in reproducing trace element abundances in the N-Izu basalts. A similar conclusion from ABS2, which explored NE Japan arc volcanic rocks was reported by Kimura et al. [2009]. Therefore, these parameters were not used in this study of N-Izu. Because of this and similar results in previous studies [e.g., Ayers, 1998], neither ABS2 nor ABS3 uses these parameters for automated fit calculations. However, users may manually alter parameters to improve fits for some specific cases, particularly where there are observed to be extremely high LILEs relative to other incompatible elements.

\subsubsection{Role of Slab Melting}

[42] The best fit results are shown graphically in Figure 6 and intensive parameters are shown in Figure 7. Overall, we found that slab fluids derived 
from dehydration are necessary for the VF basalt formation, whereas slab melts are required to produce RA basalts. To best reproduce the trace element abundances in RA basalts the slab temperature beneath the RA needed to be increased about $20 \%$ over that predicted by geodynamic estimates [Syracuse et al., 2010]. Required slab P-T conditions are $3.3-3.5 \mathrm{GPa} / 660^{\circ} \mathrm{C}-700^{\circ} \mathrm{C}$ for $\mathrm{VF}$ and 3.4-4.4 GPa $/ 830^{\circ} \mathrm{C}-890^{\circ} \mathrm{C}$ for RA (see Figure 7, top left). A similar effect (high-temperature slab) was found with ABS2 for NE Japan RA basalts [Kimura et al., 2009]. ABS2 did not deal with slab melting, therefore, the high-temperature flux for the NE Japan RA was considered to be a supercritical liquid that can carry more incompatible trace elements than a lower-temperature fluid [Kimura et al., 2009]. However, the use of supercritical liquid also produces unrealistically high estimates for $\mathrm{H}_{2} \mathrm{O}$, with the mass balance for NE Japan arc suggested up to $12 \mathrm{wt} \% \mathrm{H}_{2} \mathrm{O}$ in the RA basalts. This value appears too high for arc basalts compared to observed values [Kelley et al., 2006; Wallace, 2005]. The new ABS3 model deals with slab melting with the new phase diagrams (Text S1) and the $\mathrm{H}_{2} \mathrm{O}$ content of N-Izu RA basalts up to $\mathrm{XH}_{2} \mathrm{O}(\mathrm{BAS})=$ 1 wt $\%$ (see Figure 7) can reasonably be modeled with the adjusted P-T path.

[43] Although our geochemical mass balance predicts slab melting, we note that geodynamic models do not predict slab melting in old-cold subduction zones like N-Izu [Syracuse et al., 2010]. Recent water saturated experimental data for slab SED and AOC, [e.g., Schmidt et al., 2004; Spandler et al., 2004], also indicate no slab melting at pressure range 3-6 GPa under slab temperature less than $800^{\circ} \mathrm{C}$. The solidus temperatures of AOC and SED in the experiments (see Figure 2 in Text S1) are few tens to a hundred degrees higher than the N-Izu geotherm. However, considering that there are uncertainties associated with both geodynamic model and the experiments, we believe that slab melting remains a plausible solution. We examine this issue further below.

\subsection{Intensive and Extensive Parameters of Arc Basalt Genesis: A Forward Model Perspective}

[44] The intensive and extensive parameters estimated from the ABS3 model provide insights into the origins of the observed across-arc geochemical variations, and several important conclusions have emerged for N-Izu. We discuss these and some of the advantages and limitations of various modeling approaches in more detail below.

\subsubsection{Estimation of Degree of Partial Melting in Flux Melting}

[45] Inverse calculation models often use relatively fluid immobile elements, such as HREE and HFSE, for estimation of degree of partial melting of the mantle source [Kelley et al., 2006]. However, recent experiments suggest that HREE and HFSE are mobile even in supercritical liquid [Kessel et al., 2005] similar to slab melts [Rapp et al., 1999]. If this is the case then the problem of HREE/HFSE in the slab flux should be solved simultaneously with the mantle melting calculations. Our forward model does this using an open system melting calculation [Zou, 1998], maintaining the mass balance in the fluxed melting region.

\subsubsection{Estimation of Slab Fluid/Melt Fraction}

[46] Although trace element mass balance is maintained in the melting calculations, the effect of $\mathrm{H}_{2} \mathrm{O}$ in the mantle melting also needs to be considered. The overall role of $\mathrm{H}_{2} \mathrm{O}$ is constrained by independent data sets, such as $\mathrm{H}_{2} \mathrm{O}$ in olivine melt inclusions and estimated degrees of mantle melting determined by trace element inversion calculations [Kelley et al., 2006; Stolper and Newman, 1994]. A comparison between such estimates and parameterization based on experimental data is given in Figure 7 (bottom left). In the low $\mathrm{H}_{2} \mathrm{O}$ flux range $(<\sim 0.5 \mathrm{wt} \%$ fraction in the source), the empirical equation based on trace element inversion [Kelley et al., 2006] fits well to the experimental data [Katz et al., 2003]. However, a significant discrepancy occurs at higher degrees of fluxing. Such high degrees of slab flux $(0.5$ to $>5 \mathrm{wt} \%)$ to the subarc mantle have been estimated based on trace element and isotope data [Ishizuka et al., 2006; Kimura et al., 2009; Tollstrup et al., 2010].

[47] We have dealt with the effect of $\mathrm{H}_{2} \mathrm{O}$ in the melt/fluid-fluxed melting of the mantle peridotite [Katz et al., 2003; Kimura et al., 2009] in concert with the open system melting model for trace elements. ABS3 provides the petrological basis to solve the complex relationships involving the effects of variations in the degree of melting and amount of flux based on $\mathrm{P}(\mathrm{GPa}), \mathrm{T}(\mathrm{C})$, and $\mathrm{Xflux}(\%)$. The weakness of this forward model is the requirement for explicitly defined slab flux and mantle compositions; however, we constrain these through model mantle and slab dehydration/melting calculations. 


\subsubsection{Estimation of Slab Flux Composition}

[48] In previous studies the slab flux composition, either fluid or melt, has been examined indirectly based on the highly incompatible element pairs, such as $\mathrm{Cs} / \mathrm{Rb}$, and these geochemical characteristics have been ascribed to the role of certain slab minerals [Tamura et al., 2007]. Inverse calculations have also been used to identify the chemical compositions of the slab flux [Tollstrup et al., 2010].

[49] Our model uses petrological forward calculations for the given slab SED, AOC, PERID composition along the slab geotherm, and for the released fluids and melts from the breakdown of slab components. Progressive depletions in the trace elements and $\mathrm{H}_{2} \mathrm{O}$ from the slab are calculated as a prograde metamorphic process. The mineralogy and chemistry of the downgoing slab and thus the chemistry of the released slab fluxes at designated depths are predictable from phase equilibria and trace element partitioning models (see Figures 2-6 in Text S1). In addition the slab P-T path is now constrained for 56 arcs worldwide [Syracuse et al., 2010]. Identification of the depth where the slab flux was produced can be determined from the slab flux composition required for the mantle melting mass balance.

\subsubsection{Estimation of Source Mantle Depletion}

[50] The degree of depletion of the source mantle can be examined simultaneously with the fluxed mantle melting model, and the effects of source depletion and degree of melting can be separated by inverse calculations using HREE and HFSE element abundances as shown by Kelley et al. [2006]. However, as stated above, the effect of slab $\mathrm{H}_{2} \mathrm{O}$ on trace element behavior should be considered with such an approach. As we explicitly determine the slab flux composition, the degree of source mantle depletion from DMM can be directly calculated and the accuracy can be tested by forward fitting calculations.

\subsubsection{Estimation of Mantle Potential Temperature}

[51] Mantle potential temperature (Tp) can be estimated petrologically by a forward model using major element compositions in accumulated fractional melt for primary basalts (e.g., Kelley et al. [2006, equations 12 and 13] using $\mathrm{Na}(\mathrm{Fo} 90)$ and $\mathrm{Fe}(\mathrm{Fo} 90)$ ). A previous study by Tollstrup et al. [2010] applied this method to southern Izu and estimated $\mathrm{Tp}=1409^{\circ} \mathrm{C}-1458^{\circ} \mathrm{C}$. These are considerably higher than our estimates of $\mathrm{Tp}=1189^{\circ} \mathrm{C}$ $1267^{\circ} \mathrm{C}$ for $\mathrm{VF}$ and $\mathrm{Tp}=1249^{\circ} \mathrm{C}-1317^{\circ} \mathrm{C}$ for $\mathrm{RA}$ (Tp calculated from $\mathrm{T}(\mathrm{C})$ and $\mathrm{P}(\mathrm{GPa})$ in Figure 7). Large discrepancies are seen between the near dry $\mathrm{Na}(\mathrm{Fo} 90)-\mathrm{Fe}(\mathrm{Fo} 90)$ relation and estimated $\mathrm{Na}$ (Fo90)-Fe(Fo90) relation from the southern Izu [see Tollstrup et al., 2010, Figure 15], suggesting overestimate of Tp due to use of a dry melting model. For $\mathrm{ABS} 3$ we include explicit $\mathrm{P}-\mathrm{T}-\mathrm{XH}_{2} \mathrm{O}$ relations along with the trace element mass balance. Therefore, our estimate is based on wet mantle melting, and results in a lower estimated $\mathrm{Tp}$, which shows good agreement to wet melting $\mathrm{Tp}=1155^{\circ} \mathrm{C}-1320^{\circ}$ C calculated following Lee et al. [2009].

[52] In the ABS3 model, the mass balance is examined by controlling limited numbers of intensive/extensive parameters. As a result ABS3 is an extremely rigid forward model with a robust petrological background.

\subsection{Origin of Cross-Chain Geochemical Variation in N-Izu}

[53] On the bases of the ABS3 mass balance model results, we explore in detail the origin of the crosschain variation found in N-Izu arc.

\subsubsection{Cross-Chain Variations in Intensive/ Extensive Petrogenetic Parameters}

[54] Our model predicts that slab flux compositions for the VF and RA basalts differ significantly. For the VF, slab-derived fluids are produced at relatively low pressures $(3.3-3.5 \mathrm{GPa})$, whereas the RA melt sources are deeper (3.4-4.4 GPa, see Figure 7). Some of the major compositional differences between VF and RA slab-derived fluxes relate to the stability of lawsonite in the slab. Lawsonite breaks down at a $\sim 100 \mathrm{~km}$ depth $(3-3.5 \mathrm{GPa})$ with the slab P-T path for N-Izu (see Figure 2 in Text S1). Lawsonite breakdown releases large amount of $\mathrm{Pb}, \mathrm{Sr}$, and $\mathrm{Ba}$, contributing to the enrichment of these elements in the VF basalts. The shallow slab flux proposed by Pearce et al. [2005] for Mariana arc is primarily the signature of lawsonite breakdown predicted by ABS3.

[55] Deeper slab fluxes tend to have greater incompatible element abundances due to increases in partition coefficients of fluids or melt at higher temperatures [Kessel et al., 2005; Kimura et al., 2009]. As noted above the geodynamic estimates of slab temperature are not sufficiently high to reproduce slab flux compositions and needs to be 
increased by $\sim 20 \%$ (about $150^{\circ} \mathrm{C}$ ) greater than predicted by the geodynamic model. With these higher temperatures, the ABS3 model predicts slab melts for RA basalt. This conclusion is consistent with the previous proposals based on incompatible element and isotope data [Hochstaedter et al., 2001; Ishizuka et al., 2003]. Moreover, melting of the slab decomposes mica minerals (phengite) in the slab (see Figure 2 in Text S1), resulting in release of $\mathrm{K}, \mathrm{Rb}$, and $\mathrm{Cs}$. Combined with residual garnet and clinopyroxene in the slab, the geochemical characteristics of RA flux is derived from this breakdown. Additional fluid release also results from these dehydration melting reactions, but the amount is much less than released beneath the VF $(<1.5$ wt $\%$ in slab melt, see Figure 7$)$. Our ABS3 model explicitly predicts the role of phengite breakdown in the slab, which was caused by slab melting.

[56] The degree of partial melting of the mantle PERID is predicted to be greater beneath VF $(\mathrm{F}=$ $21 \%-30 \%)$ and smaller beneath the RA ( $\mathrm{F}=9-16$ or $1 \%-1.5 \%$ in slab melt fluxed mantle melting, Figure 7), and the temperature of melting is higher in the mantle wedge beneath the RA $\left(1260^{\circ} \mathrm{C}-\right.$ $\left.1340^{\circ} \mathrm{C}\right)$ and lower in $\operatorname{VF}\left(1200^{\circ} \mathrm{C}-1270^{\circ} \mathrm{C}\right)$. Melting pressure should also be lower beneath the VF (1.0-1.3 GPa) compared to the RA (1.3-1.5 or 2.0-2.3 GPa, Figure 7). The lower melting degree with greater pressure allows residual garnet in the RA PERID source. Therefore, elevated LREE/ HFSEs observed in the RA lavas are primarily the result of combined lower melting degree and residual garnet in the source (see Software S1). The melting conditions for the RA lavas are apparently in two distinct regions (Figure 7); however, these are due to a strong statistical filter used in the fitting calculations. The fitting region lies between the two regions (shown by light blue thick line) indicating that there are less constraints on the melting conditions under the RA. Even so, the conditions for RA melting are clearly different from those for the VF lavas. The estimates on degree of mantle melting based on Kelley et al.'s [2006] inverse calculation method yield degree of melting for $\mathrm{VF}$ at $31 \pm 6 \%$ and for RA $17 \pm 3 \%$, and these are comparable to our maximum estimates. The Kelley et al. [2006] estimates are probably somewhat higher than ours as they do not account for mobility of HREE and HFSE in the slab fluxes added to the melting regions. Mantle melting temperatures $\left(1200^{\circ} \mathrm{C}-1340^{\circ} \mathrm{C}\right)$ estimated by the ABS3 model are petrologically consistent with the pressure estimates and flux fractions (see section 5.3.3.). Therefore, the extremely high mantle temperatures suggested by Tollstrup et al. [2010] are not required to satisfy the trace element mass balance and the melting relationship, and the idea that unusually high mantle temperature is the source of deep slab melting [Tollstrup et al., 2010] is not supported. High slab temperatures, as deduced by temperature-dependent olivine rheology [Syracuse et al., 2010] and by our geochemical constraints are the alternative solution.

[57] The flux fraction is variable beneath the RA (1-1.5 to $4.5-5 \mathrm{wt} \%$ melt) and typically larger beneath the VF (2-4 wt \% fluid, Figure 7). PERID melting degree is broadly proportional to the flux fraction, although the effect of fluxing is different between an aqueous fluid (VF) and melt (RA). This is due to different $\mathrm{H}_{2} \mathrm{O}$ contents between fluid and melt. The greater $\mathrm{H}_{2} \mathrm{O}$ addition beneath the VF is the prime control of mantle melting degree, and is responsible for the high VF magma production. This supports a previous inference derived from ABS1 and ABS2 calculations [Kimura and Stern, 2008; Kimura et al., 2009]. It is also consistent with the fact that fluid release by slab dehydration is at a maximum at $\sim 3 \mathrm{GPa}$ by breakdown of amphibole and lawsonite to form phengite quartz eclogite (amphibolite - eclogite transformation) (see Figure 2 in Text S1). The ABS3 model provides the petrological basis to examine the connection between focused high slab defluxing and high magma production rate. This has been predicted based on experimental data [Poli and Schmidt, 1995].

[58] An additional feature is that a more depleted mantle PERID than those of MORB source is required for both the VF and RA sources. This interpretation appears to be inconsistent with the fact that the Shikoku Back Arc Basin basalts are derived from a MORB source mantle [HickeyVargas, 1991, 1998; Hickey-Vargas et al., 1995; Machida et al., 2008]. However, extraction of MORB-type basalts to form BAB in the Miocene should have depleted the RA mantle source, and this may be the source that later melts to produce Quaternary RA and VF basalts. Progressive younging of volcanic activity from RA to VF after the Miocene [Ishizuka et al., 2006] may suggest inflow of the depleted deep and hot mantle beneath the N-Izu arc. Depletion of the PERID by the extraction of the RA melts is another option [Hochstaedter et al., 2001], but this does not account for mantle depletion in the RA source found in this study and Tollstrup et al. [2010]. Our model does not quantitatively evaluate Hochstaedter et al.'s 
[2001] semidynamic model and such a process makes interpreting cross-chain geochemical variations more complex [Kimura and Stern, 2008]. This may also lead to difficulties in interpreting the cause of the cross-chain K-h relationship [Dickinson, 1975; Dickinson and Hatherton, 1967; Hatherton and Dickinson, 1969]. A dynamic model to study this further is beyond the scope of this paper; however, ABS3 would potentially be useful for future studies aimed at constraining possible sources of mantle heterogeneity. The existence of variably depleted mantle sources has also been reported in the central to southern N-Izu [Machida et al., 2008].

[59] Further studies of fluid immobile isotopes, such as $\mathrm{Nd}$ and Hf, will be useful to identify the relationship between source depletion and role of slab melt flux [Ishizuka et al., 2006]. In fact, Tollstrup et al. [2010] examined the HFSE behavior along with Hf isotopes and concluded that slab meltderived HFSE contributed to the greater Nd and Hf variation found in RA basalts. With the present ABS3 model, evaluation of HFSE behavior is a problem because HFSE behavior in the slab flux is largely controlled by minor Ti-bearing phases or zircon, and the stability relations of these phases is poorly constrained by Perple_X phase model that we use. Consumption of these phases during melting may account for $\mathrm{Hf} / \mathrm{Hf}^{*}$ variations (Hf depletion or enrichment factor relative to $\mathrm{Nd}$ and $\mathrm{Sm}$ in a normalized plot) [Tollstrup et al., 2010; Tollstrup and Gill, 2005]. This question is left open for further development of the ABS model that includes the effect of those minor mineral phases once improved experimental constraints are available.

[60] Finally, the estimated $\mathrm{H}_{2} \mathrm{O}$ contents in primary magmas (fraction of fluid flux in terms of open system melting [Ozawa and Shimizu, 1995]) are greater in the VF (5-8 wt \%) and less in the RA (1-1.5 wt \% irrespective of large variation in the melt flux due to the counterbalancing effect of melting degree, Figure 7). Although $\mathrm{H}_{2} \mathrm{O}$ contents of N-Izu olivine melt inclusions are not yet known, there is evidence that the VF basalts are more fluidrich than in the RA basalts. This is also consistent with the general water contents measured in VF and RA settings worldwide [Wallace, 2005; Kelley et al., 2006]. Water in the N-Izu VF basalt magmas has been estimated to be $3-6$ wt \% based on melt plagioclase element partitioning [Hamada and Fujii, 2007]. The minimum $\mathrm{H}_{2} \mathrm{O}$ contents in the primary melt estimated by ABS3 was 5 wt \%, and thus is broadly consistent with the petrological estimates. Estimates of primary magmatic $\mathrm{H}_{2} \mathrm{O}$ contents based in $\mathrm{ABS} 3$ are somewhat higher in the VF basalts than measured water contents in Izu tephras and the Mariana fore-arc basalts [Elliott et al., 1997; Straub and Layne, 2003], although these could have been affected by degassing. The general trend, of increasing $\mathrm{H}_{2} \mathrm{O}$ from VF to BAB, is consistent with the previous studies [Kelley et al., 2006]. Water contents in RA basalts from the southern Izu have water contents from 0.5 to $2.5 \mathrm{wt} \%$ (A. J. R. Kent, unpublished data, 2009), which is also consistent with our general predictions. Constrain on magmatic water contents in N-Izu basalts from olivine-hosted melt inclusions or other sources would provide an important further test of our model.

\subsubsection{P-T Structure of the Slab and the Mantle Wedge}

[61] We can also use our ABS3 results to reconstruct the P-T structure in the slab and the mantle wedge (Figure 8). From the compositions of the VF and RA basalts, we can derive several control points in the slab dehydration and mantle melting regions. We suggest that the slab-mantle P-T conditions from bottom to top are as follows: Slab dehydration is estimated to occur at $3.0-3.3 \mathrm{GPa} / 660^{\circ} \mathrm{C}-$ $700^{\circ} \mathrm{C}$ beneath the VF and slab melting occurs 3.6-4.4 GPa $/ 830^{\circ} \mathrm{C}-890^{\circ} \mathrm{C}$ beneath the RA. Mantle melting conditions of the VF basalt range from 1.3 to $1.0 \mathrm{GPa} / 1200^{\circ} \mathrm{C}-1270^{\circ} \mathrm{C}$ and $2.3-2.0 \mathrm{GPa} /$ $1340^{\circ} \mathrm{C}-1300^{\circ} \mathrm{C}$ for RA basalts.

[62] As discussed above, the RA magmas sample only the shallowest portion of the mantle that melts. Deeper RA mantle should also melt because the wedge core temperature may exceed $1400^{\circ} \mathrm{C}$ [Syracuse et al., 2010]. The Shikoku back arc basin basalts are key to further constraining the rear-arc geotherm, The Shikoku Basin was actively spreading until $15 \mathrm{Ma}$ and the youngest ocean basement immediately behind the N-Izu rear arc is about $28 \mathrm{Ma}$, forming when the $\mathrm{BAB}$ first opened [Okino et al., 1994]. Therefore, the $1000^{\circ} \mathrm{C}$ isotherm depth should follow the oceanic lithosphere cooling rate to lie $\sim 30 \mathrm{~km}$ deep beneath N-Izu rear arc (Figure 8). It is possible with this situation that the $1300^{\circ} \mathrm{C}-1400^{\circ} \mathrm{C}$ geotherm is located $\sim 100 \mathrm{~km}$ deep beneath the rear arc (see Figure 8). In this case, the melting column may extend down to $150-170 \mathrm{~km}$ deep (4-5 GPa) in the RA mantle (see melting columns in red in Figure 8) according to the estimate using $P-T-X \mathrm{H}_{2} \mathrm{O}$ parameterization of Katz et al. [2003].

[63] Based on the P-T control points deduced from the ABS3 model and other constraints (see Figure 8), 


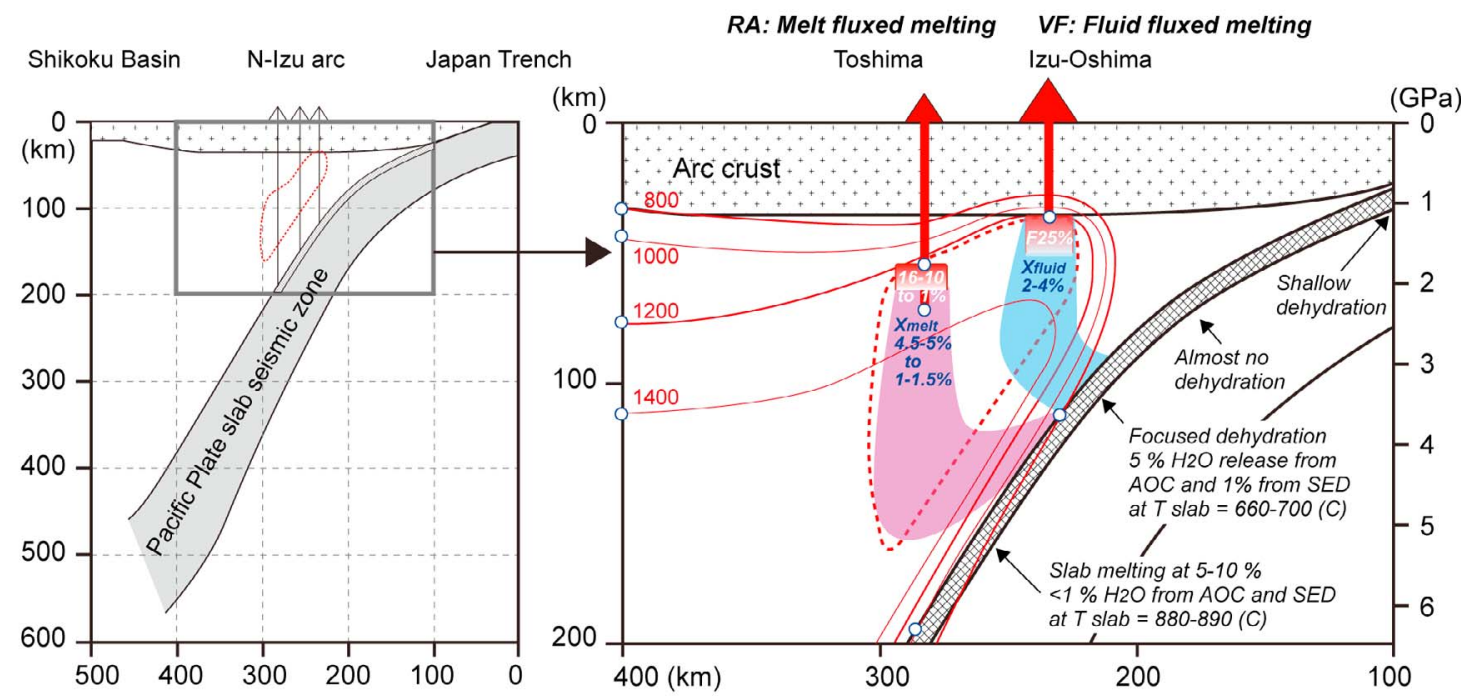

Figure 8. Schematic cross section of N-Izu volcanic arc. (left) Distribution of seismic zone beneath Izu-Oshima to Niijima cross chain [Stern et al., 2003]. Izu-Oshima volcano is located above the $120 \mathrm{~km}$ depth contour of the Wadati-Beiioff zone, whereas Toshima and Niijima are situated on about $180 \mathrm{~km}$ depth contour. (right) Distribution of slab fluid path (shaded cold color regions) and mantle melting region (red gradational color regions) with estimated isotherm in the mantle wedge. The isotherms are constrained by the rear-arc geotherm (intermediate between spreading ridge and average ocean geotherm because the Shikoku Basin has been extinct since $15 \mathrm{Ma}$ ); temperature of magma segregation depths; and slab surface temperatures estimated for Izu-Oshima, Toshima, and Niijima basalt sources. P-T control points are given by open circles. Slab dehydration focuses on two regions, one beneath the fore $\operatorname{arc}(\sim 1 \mathrm{GPa})$ and the other at about $120 \mathrm{~km}$ depth $(\sim 3 \mathrm{GPa})$ with the given slab surface temperature (SST) trajectory (for SST see details in section 5.4.2). Characteristics of this model are (1) fluids liberated from the slab rise up to the mantle melting region and (2) mantle melting takes place almost parallel to the slab surface, controlled by $1200^{\circ} \mathrm{C}$ and $1400^{\circ} \mathrm{C}$ isotherms. The deeper limit of the melting region is controlled by $\mathrm{P}-\mathrm{T}-\mathrm{XH}_{2} \mathrm{O}$ relation [Katz et al., 2003] at 1about $2.7 \mathrm{GPa} / \sim 1400^{\circ} \mathrm{C}$ for $\mathrm{VF}$ and $3.5 \mathrm{GPa} / \sim 1500^{\circ} \mathrm{C}$ for RA. The parallel melting zone developed between 1 and $3.5 \mathrm{GPa}$ in the mantle wedge is detected seismologically in NE Japan arc [Hasegawa et al., 1991; Nakajima and Hasegawa, 2003; Nakajima et al., 2005]. Such structure is thus common beneath basaltic arcs.

there are significant variation in magma production conditions beneath the magmatic arc. First, the slab dehydration is focused at $\sim 3 \mathrm{GPa}$ and this results in greater production of basalt magmas beneath the VF. The melting column would lie $\sim 35-80 \mathrm{~km}(2.5-$ $1.0 \mathrm{GPa}$ ) deep with a temperature range of $1200^{\circ} \mathrm{C}-$ $1400^{\circ} \mathrm{C}$. Second, the rear-arc slab melting occurs at $140 \mathrm{~km}(3.5 \mathrm{GPa})$ and $890^{\circ} \mathrm{C}$. The melting column may range from $>170 \mathrm{~km}$ deep $(5 \mathrm{GPa})$ and $1400^{\circ} \mathrm{C}$ to $\sim 80 \mathrm{~km}$ deep $(2.5 \mathrm{GPa})$ and $1200^{\circ} \mathrm{C}$. The mantle melting volume is continuous and forms a region in the mantle wedge which is subparallel to the slab surface (see dotted oval areas in Figure 8). A similar mantle wedge structure has been inferred in the NE Japan arc, based on seismic tomography [Hasegawa et al., 1991; Nakajima et al., 2005] that shows a slab parallel low- $V p$ and low- $V S$ zone is found in the middle of the mantle wedge. The shallowest part of the melting region is about $1 \mathrm{GPa}$ and can involve the deepest arc crust [Hasegawa et al., 1991;
Kimura et al., 2002; Nakajima et al., 2005; Tatsumi et al., 2008], similar to estimates from our ABS3 modeling. Although the geophysical methods estimate mantle wedge temperatures [Nakajima and Hasegawa, 2003] that are $\sim 200^{\circ} \mathrm{C}$ lower than the ABS3 estimates, the overall $\mathrm{P}-\mathrm{T}$ structure in the wedge mantle is similar between the two approaches.

[64] It is also worth noting that if $X \mathrm{H}_{2} \mathrm{O}$ is zero in such a mantle wedge $P-T$ structure, melt can only be generated beneath the VF at a depth of $50-65 \mathrm{~km}$ (1.5-2.5 GPa) with $<3 \%$ partial melting, and no melt is generated in the RA environment according to the Katz et al. [2003] model. This emphasizes the critical role of slab-derived $\mathrm{H}_{2} \mathrm{O}$ in generating a large $(10 \%-25 \%)$ amount of melting. The role of water is critical even for trace amounts, such as if $0.1 \%$ water is added, the mantle can generate $>3 \%$ more melt due to fluid fluxed melting. The presence or absence of $\mathrm{H}_{2} \mathrm{O}$ is thus also critical in determining the width of the volcanic arc and its magma production. 
[65] The P-T structure constrained by the ABS3 model is broadly consistent with that inferred from seismological constraints. Improving the model requires further development and integration of the phase petrology, element partitioning, and dynamics of the fluid and the solid flows in the slab and the mantle wedge.

\section{Conclusions}

[66] The intensive and extensive variables in the slab and in the mantle that determine the geochemical variations observed in N-Izu cross-chain volcanism are summarized as follows.

\subsection{Cross-Chain Variations in Slab Fluids}

[67] The slab mineralogy changes along the slab $P-T$ path. Shallow slab fluid release is focused at $\sim 3 \mathrm{GPa}$, corresponding to the breakdown of amphibole and lawsonite. This shallow fluid dehydration possesses elevated LILEs such as $\mathrm{Ba}, \mathrm{K}, \mathrm{Pb}$, and Sr primarily due to the lawsonite breakdown. In contrast, deeper slab melt is controlled by phengitequartz-eclogite mineralogy and has more incompatible elements entering into the melt due to the dependence on partition coefficients. The resultant deep melts are LILE- and LREE-rich and relatively elevated in HFSE and HREE. The shallow and deep fluids contribute to mantle melting and basalt genesis in the VF and RA, respectively.

\subsection{Cross-Chain Variations in Fluid Flux and Mantle Melting Degree and Depth}

[68] About twice as much flux is added to the mantle beneath the VF than beneath the RA, and the greater addition of fluid, thus $\mathrm{H}_{2} \mathrm{O}$, in addition to lower pressures promotes more extensive mantle melting. The RA mantle experiences lower melt flux, consistent with melting of dryer phengite quartz eclogite in the deeper subducted slab. Diminished fluid flux along with high melting pressure suppresses the degree of melting of the RA mantle, resulting in elevated incompatible element abundances in RA basalts. Such a wedge mantle structure is consistent with seismic observations in other arcs, such as NE Japan [Hasegawa et al., 1991; Nakajima et al., 2005]. These melting depths and degrees were obtained independently from petrologic constraints by the ABS3 model using incompatible trace elements, but are quite consistent with crosschain models deduced from major element petrology [Kimura and Yoshida, 2006; Tatsumi et al., 1983].

\subsection{Cross-Chain Variations in Radiogenic Isotopes}

[69] Radiogenic $\mathrm{Pb}$ and $\mathrm{Sr}$ are dominant in the $\mathrm{VF}$ mantle source due to high fluid fraction and the greater abundances of these elements in the slab fluid. In contrast, radiogenic $\mathrm{Nd}$ and $\mathrm{Hf}$ in $\mathrm{VF}$ basalts reflect smaller contributions of these fluid immobile elements to the mantle source due to very low abundances of $\mathrm{Nd}$ and $\mathrm{Hf}$ in the same fluid. Less radiogenic $\mathrm{Sr}$ and $\mathrm{Pb}$ in $\mathrm{RA}$ basalts reflect the greater contribution of mantle sources due to lower degrees of partial melting and relatively high addition of deep melts into the basalt melts.

\subsection{Fluid Flux, Mantle Melting, and Volatiles in Cross-Chain Basalts}

[70] The fluid flux fraction in the mantle appears to be greater in the VF. The degree of mantle melting is roughly controlled by the flux. The $\mathrm{H}_{2} \mathrm{O}$ contents estimated for primary basalt are consistent with geohygrometry (4-6 wt \% in VF) [Hamada and Fujii, 2007].

[71] We have shown that the origins of cross-chain geochemical variation are largely controlled by slab and mantle wedge conditions, which in turn are petrologically controlled by the $P-T$ structure in the slab and mantle wedge.

\section{Acknowledgments}

[72] We thank Barry Roser, Yoshiyuki Sawada, and Shigeru Iizumi (Shimane University); Yoshiyuki Tatsumi and Alex Nichols (IFREE-JAMSTEC); and James Gill (University of California, Santa Cruz) for help and discussions. A.J.R.K. also received support from the National Science Foundation (OCE-0305755) for this study. Constructive reviews by an anonymous reviewer and Editor Joel Baker improved this manuscript significantly.

\section{References}

Arculus, R. J., and R. W. Johnson (1981), Island-arc magma sources: A geochemical assessment of the roles of slabderived components and crustal contamination, Geochem. J., 15, 109-133.

Ayers, J. (1998), Trace element modeling of aqueous fluidperidotite interaction in the mantle wedge of subduction zones, Contrib. Mineral. Petrol., 132, 390-404, doi:10.1007/ s004100050431.

Bebout, G. E., J. G. Ryan, W. P. Leeman, and A. E. Bebout (1999), Fractionation of trace elements by subduction-zone metamorphism-Effect of convergent-margin thermal evolution, Earth Planet. Sci. Lett., 171, 63-81, doi:10.1016/ S0012-821X(99)00135-1. 
Blichert-Toft, J., C. Chauvel, and F. Albarède (1997), Separation of $\mathrm{Hf}$ and $\mathrm{Lu}$ for high-precision isotope analysis of rock samples by magnetic sector-multiple collector ICP-MS, Contrib. Mineral. Petrol., 127, 248-260, doi:10.1007/ s004100050278.

Carr, M. J., I. Saginor, G. E. Alvarado, L. L. Bolge, F. N. Lindsay, K. Milidakis, B. D. Turrin, M. D. Feigenson, and C. C. Swisher III (2007), Element fluxes from the volcanic front of Nicaragua and Costa Rica, Geochem. Geophys. Geosyst., 8, Q06001, doi:10.1029/2006GC001396.

Churikova, T., F. Drendorf, and G. Wörner (2001), Sources and fluids in the mantle wedge below Kamchatka, evidence from across-arc geochemical variation, J. Petrol., 42, 1567-1593, doi:10.1093/petrology/42.8.1567.

Dickinson, W. R. (1975), Potash-depth (K-h) relations in continental margins and intra-oceanic magmatic arcs, Geology, 3, 53-56, doi:10.1130/0091-7613(1975)3<53:PKRICM>2.0. $\mathrm{CO} ; 2$.

Dickinson, W. R., and T. Hatherton (1967), Andesitic volcanism and seismicity around the Pacific, Science, 157, 801-803, doi:10.1126/science.157.3790.801.

Elliott, T., T. Plank, A. Zindler, W. White, and B. Bourdon (1997), Element transport from slab to volcanic front at the Mariana arc, J. Geophys. Res., 102(B7), 14,991-15,019, doi:10.1029/97JB00788.

Ghiorso, M. S., M. M. Hirschmann, P. W. Reiners, and V. C. Kress (2002), The pMELTS: A revision of MELTS for improved calculation of phase relations and major element partitioning related to partial melting of the mantle to $3 \mathrm{GPa}$, Geochem. Geophys. Geosyst., 3(5), 1030, doi:10.1029/ $2001 \mathrm{GC} 000217$.

Gill, J. B. (1981), Orogenic Andesites and Plate Tectonics, 385 pp., Springer, Heidelberg, Germany.

Green, T. H. (1995), Significance of $\mathrm{Nb} / \mathrm{Ta}$ as an indicator of geochemical processes in the crust-mantle system, Chem. Geol., 120, 347-359, doi:10.1016/0009-2541(94)00145-X.

Hacker, B. R. (2008), $\mathrm{H}_{2} \mathrm{O}$ subduction beyond arcs, Geochem. Geophys. Geosyst., 9, Q03001, doi:10.1029/2007GC001707.

Hamada, M., and T. Fujii (2007), $\mathrm{H}_{2} \mathrm{O}$-rich island arc low-K tholeiite magma inferred from $\mathrm{Ca}$-rich plagioclase-melt inclusion equilibria, Geochem. J., 41, 437-461.

Hanyu, T., S. Nakai, and R. Tatsuta (2005), Hafnium isotope ratios of nine GSJ reference samples, Geochem. J., 39, 83-90, doi:10.2343/geochemj.39.83.

Hasegawa, A., D. Zhao, S. Hori, A. Yamamoto, and S. Horiuchi (1991), Deep structure of the northeastern Japan arc and its relationship to seismic and volcanic activity, Nature, 352, 683-689, doi:10.1038/352683a0.

Hatherton, T., and W. R. Dickinson (1969), The relationship between andesitic volcanism and seismicity in Indonesia, $J$. Geophys. Res., 74, 5301-5310, doi:10.1029/JB074i022p05301.

Hauff, F., K. Hoernle, and A. Schmidt (2003), Sr-Nd-Pb composition of Mesozoic Pacific oceanic crust (Site 1149 and 801, ODP Leg 185): Implications for alteration of ocean crust and the input into the Izu-Bonin-Mariana subduction system, Geochem. Geophys. Geosyst., 4(8), 8913, doi:10.1029/ 2002GC000421.

Hickey-Vargas, R. (1991), Isotope characteristics of submarine lavas from the Philippine Sea: Implications for the origin of arc and basin magmas of the Philippine tectonic plate, Earth Planet. Sci. Lett., 107, 290-304, doi:10.1016/0012-821X (91)90077-U.

Hickey-Vargas, R. (1998), Origin of the Indian Ocean-type isotopic signature in basalts from Philippine Sea plate spreading centers: An assessment of local versus large-scale processes, J. Geophys. Res., 103, 20,963-20,979, doi:10.1029/98JB02052.

Hickey-Vargas, R., J. M. Hergt, and P. Spadea (1995), The Indian Ocean-type isotopic signature in western Pacific marginal basins: Origin and significance, in Active Margins and Marginal Basins of the Western Pacific, Geophys. Monogr. Ser., vol. 88, edited by B. Taylor and J. Natland, pp. 175-197, AGU, Washington, D. C.

Hochstaedter, A., J. Gill, R. Peters, P. Broughton, P. Holden, and B. Taylor (2001), Across-arc geochemical trends in the Izu-Bonin arc: Contributions from the subducting slab, Geochem. Geophys. Geosyst., 2(7), 1019, doi:10.1029/ 2000GC000105.

Iizumi, S., K. Maehara, P. A. Morris, and Y. Sawada (1994), $\mathrm{Sr}$ isotope data of some GSJ rock reference samples, Mem. Fac. Sci. Shimane Univ., 28, 83-86.

Iizumi, S., P. A. Morris, and Y. Sawada (1995), Nd isotope data for GSJ reference samples JB-1a, JB-3 and JG-1a and the La Jolla standard, Mem. Fac. Sci. Shimane Univ., 29, 73-76.

Ishikawa, T., and F. Tera (1999), Two isotopically distinct fluid components involved in the Mariana Arc: Evidence from $\mathrm{Nb} / \mathrm{B}$ ratios and $\mathrm{B}, \mathrm{Sr}, \mathrm{Nd}$, and $\mathrm{Pb}$ isotope systematics, Geology, 27, 83-86, doi:10.1130/0091-7613(1999) 027<0083:TIDFCI $>2.3$.CO;2.

Ishizuka, O., R. N. Taylor, J. A. Milton, and R. W. Nesbitt (2003), Fluid-mantle interaction in an intra-oceanic arc: Constraints from high-precision $\mathrm{Pb}$ isotopes, Earth Planet. Sci. Lett., 211, 221-236, doi:10.1016/S0012-821X(03) 00201-2.

Ishizuka, O., R. N. Taylor, J. A. Milton, R. W. Nesbitt, M. Yuasa, and I. Sakamoto (2006), Variation in the mantle sources of the northern Izu arc with time and spaceConstraints from high-precision $\mathrm{Pb}$ isotopes, J. Volcanol. Geotherm. Res., 156, 266-290, doi:10.1016/j.jvolgeores. 2006.03.005.

Isshiki, N. (1977), Geology of the Toshima District, 35 pp., Geol. Surv. of Jpn., Tsukuba, Japan.

Isshiki, N. (1984), Geology of the Oshima District, 133 pp., Geol. Surv. of Jpn., Tsukuba, Japan.

Isshiki, N. (1986), Geology of the Nii Jima District, 85 pp., Geol. Surv. of Jpn., Tsukuba, Japan.

Jicha, B. R., B. S. Singer, J. G. Brophy, J. H. Fournelle, C. M. Johnson, B. L. Beard, T. J. Lapen, and N. J. Mahlen (2004), Variable impact of the subducted slab on Aleutian island arc magma sources: Evidence from $\mathrm{Sr}, \mathrm{Nd}, \mathrm{Pb}$, and $\mathrm{Hf}$ Isotopes and trace element abundances, J. Petrol., 45, 1845-1875, doi:10.1093/petrology/egh036.

Katz, R. F., M. Spiegelman, and C. H. Langmuir (2003), A new parameterization of hydrous mantle melting, Geochem. Geophys. Geosyst., 4(9), 1073, doi:10.1029/2002GC000433.

Kelley, K. A., T. Plank, J. Ludden, and H. Staudigel (2003), Composition of altered oceanic crust at ODP Sites 801 and 1149, Geochem. Geophys. Geosyst., 4(6), 8910, doi:10.1029/2002GC000435.

Kelley, K. A., T. Plank, T. L. Grove, E. M. Stolper, S. Newman, and E. Hauri (2006), Mantle melting as a function of water content beneath back-arc basins, J. Geophys. Res., 111, B09208, doi:10.1029/2005JB003732.

Kersting, A. B., R. J. Arculus, and D. A. Gust (1996), Lithospheric contributions to arc magmatism: Isotope variations along strike in volcanoes of Honshu, Japan, Science, 272, 1464-1468, doi:10.1126/science.272.5267.1464.

Kessel, R., M. W. Schmidt, P. Ulmer, and T. Pettke (2005), Trace element signature of subduction-zone fluids, melts 
and supercritical liquids at 120-180 km depth, Nature, 437 , 724-727.

Kimura, J.-I., and R. J. Stern (2008), Neogene volcanism of the Japan island arc: The K-h relationship revisited, in CircumPacific Tectonics, Geologic Evolution, and Ore Deposits, Ariz. Geol. Soc. Dig., vol. 22, edited by J. E. Spencer and S. R. Titley, pp. 187-202, Ariz. Geol. Soc., Tucson.

Kimura, J.-I., and Y. Yamada (1996), Evaluation of major and trace element XRF analyses using a flux to sample ratio of two to one glass beads, J. Mineral. Petrol. Econ. Geol., 91, 62-72, doi:10.2465/ganko.91.62.

Kimura, J.-I., and T. Yoshida (2006), Contributions of slab fluid, mantle wedge and crust to the origin of Quaternary lavas in the NE Japan arc, J. Petrol., 47, 2185-2232, doi:10.1093/ petrology/egl041.

Kimura, J.-I., T. Yoshida, and Y. Takaku (1995), Igneous rock analysis using ICP-MS with internal standardization, isobaric ion overlap correction, and standard addition methods, Sci. Rep. Fukushima Univ., 56, 1-12.

Kimura, J.-I., T. Yoshida, and S. Iizumi (2002), Origin of low-K intermediate lavas at Nekoma volcano, NE Honshu arc, Japan: Geochemical constraints fro lower-crustal melts, J. Petrol., 43, 631-661, doi:10.1093/petrology/43.4.631.

Kimura, J.-I., R. J. Stern, and T. Yoshida (2005), Re-initiation of subduction and magmatic responses in SW Japan during Neogene time, Geol. Soc. Am. Bull., 117, 969-986, doi:10.1130/B25565.1

Kimura, J.-I., T. W. Sisson, N. Nakano, M. L. Coombs, and P. W. Lipan (2006), Geochemistry of early Kilauea magmas from the submarine Hilina bench: The nature of the Hilina mantle component, J. Volcanol. Geotherm. Res., 151, 51-72, doi:10.1016/j.jvolgeores.2005.07.024.

Kimura, J.-I., P. van Keken, B. R. Hacker, H. Kawabata, T. Yoshida, and R. J. Stern (2009), Arc Basalt Simulator version 2, a simulation for slab dehydration and fluid-fluxed mantle melting for arc basalts: Modeling scheme and application, Geochem. Geophys. Geosyst., 10, Q09004, doi:10.1029/ $2008 \mathrm{GC} 002217$.

Kodaira, S., T. Sato, N. Takahashi, A. Ito, Y. Tamura, Y. Tatsumi, and Y. Kaneda (2007), Seismological evidence for variable growth of crust along the Izu intraoceanic arc, J. Geophys. Res., 112, B05104, doi:10.1029/ 2006JB004593.

Lee, C.-T. A., P. Luffi, T. Plank, H. Dalton, and W. P. Leeman (2009), Constraints on the depths and temperatures of basaltic magma generation on Earth and other terrestrial planets using new thermobarometers for mafic magmas, Earth Planet. Sci. Lett., 279, 20-33, doi:10.1016/j.epsl.2008.12.020.

LeMaitre, R. W., et al. (1989), A Classification of Igneous Rocks and Glossary of Terms, Blackwell, Oxford, U. K.

Machida, S., T. Ishii, J.-I. Kimura, S. Awaji, and Y. Kato (2008), Petrology and geochemistry of cross-chains in the Izu-Bonin back arc: Three mantle components with contributions of hydrous liquids from a deeply subducted slab, Geochem. Geophys. Geosyst., 9, Q05002, doi:10.1029/ 2007GC001641.

Miyashiro, A. (1974), Volcanic rock series in island arcs and active continental margins, Am. J. Sci., 274, 321-355.

Moriguti, T., T. Shibata, and E. Nakamura (2004), Lithium, boron and lead isotope and trace element systematics of Quaternary basaltic volcanic rocks in northeastern Japan: Mineralogical controls on slab-derived fluid composition, Chem. Geol., 212, 81-100, doi:10.1016/j.chemgeo.2004.08.005.

Nakajima, J., and A. Hasegawa (2003), Estimation of thermal structure in the mantle wedge of northeastern Japan from seismic attenuation data, Geophys. Res. Lett., 30(14), 1760, doi:10.1029/2003GL017185.

Nakajima, J., Y. Takei, and A. Hasegawa (2005), Quantitative analysis of the inclined low-velocity zone in the mantle wedge of northern Japan: A systematic change of melt-filled pore shapes with depth and its implications for melt migration, Earth Planet. Sci. Lett., 234, 59-70, doi:10.1016/j. eps1.2005.02.033.

Nakanishi, M., K. Tamaki, and K. Kobayashi (1992), Magnetic anomaly lineations from Late Jurassic to Early Cretaceous in the west-central Pacific Ocean, Geophys. J. Int., 109, 701-719, doi:10.1111/j.1365-246X.1992.tb00126.x.

Nakano, S., and T. Yamamoto (1991), Chemical variations of magmas at Izu-Oshima volcano, Japan: Plagioclase-controlled and differentiated magmas, Bull. Volcanol., 53, 112-120, doi:10.1007/BF00265416.

Okino, K., Y. Shimakawa, and S. Nagaoka (1994), Evolution of the Shikoku Basin, J. Geomagn. Geoelectr., 46, 463-479.

Ozawa, K., and N. Shimizu (1995), Open-system melting in the upper mantle: Constraints from the HayachineMiyamori ophiolite, northeastern Japan, J. Geophys. Res., 100, 22,315-22,335, doi:10.1029/95JB01967.

Pearce, J. A., and I. J. Parkinson (1993), Trace element models for mantle melting: Application to volcanic arc petrogenesis, in Magmatic Processes and Plate Tectonics, edited by H. M. Prichard et al., Geol. Soc. Spec. Publ., 76, 373-403.

Pearce, J. A., P. E. Baker, P. K. Harvey, and I. W. Luff (1995), Geochemical evidence for subduction fluxes, mantle melting and fractional crystallization beneath the South Sandwich Island arc, J. Petrol., 36, 1073-1109.

Pearce, J. A., R. J. Stern, S. H. Bloomer, and P. Fryer (2005), Geochemical mapping of the Mariana arc-basin system: Implications for the nature and distribution of subduction components, Geochem. Geophys. Geosyst., 6, Q07006, doi:10.1029/2004GC000895.

Peate, D. W., J. A. Pearce, C. J. Hawkesworth, H. Colly, C. M. H. Edwards, and K. Hirose (1997), Geochemical variations in Vanuatu arc lavas: The role of subducted material and a variable mantle wedge composition, J. Petrol., 38, 1331-1358, doi:10.1093/petrology/38.10.1331.

Peccerillo, A., and S. R. Taylor (1976), Geochemistry of Eocene calc-alkaline volcanic rocks from the Kastamonu area, northern Turkey, Contrib. Mineral. Petrol., 58, 63-81, doi:10.1007/BF00384745.

Plank, T., and C. H. Langmuir (1998), The chemical composition of subducting sediment and its consequence for the crust and mantle, Chem. Geol., 145, 325-394, doi:10.1016/S00092541(97)00150-2.

Plank, T., K. A. Kelley, R. W. Murray, and L. Q. Stern (2007), Chemical composition of sediments subducting at the IzuBonin trench, Geochem. Geophys. Geosyst., 8, Q04I16, doi:10.1029/2006GC001444.

Poli, S., and M. W. Schmidt (1995), $\mathrm{H}_{2} \mathrm{O}$ transport and release in subduction zones: Experimental constraints on basaltic and andesitic systems, J. Geophys. Res., 100(B11), 22,299-22,314, doi:10.1029/95JB01570.

Rapp, R. P., N. Shimizu, M. D. Norman, and G. S. Applegate (1999), Reaction between slab-derived melts and peridotite in the mantle wedge: Experimental constraints at $3.8 \mathrm{GPa}$, Chem. Geol., 160, 335-356, doi:10.1016/S0009-2541(99) 00106-0.

Richard, P., N. Shimizu, and C. J. Allègre (1976), ${ }^{143} \mathrm{Nd} /{ }^{146} \mathrm{Nd}$, a natural tracer: An application to oceanic basalts, Earth Planet. Sci. Lett., 31, 269-278, doi:10.1016/0012-821X (76)90219-3. 
Sadofsky, S. J., M. Portnyagin, K. Hoernle, and P. van den Bogaard (2008), Subduction cycling of volatiles and trace elements through the Central American volcanic arc: Evidence from melt inclusions, Contrib. Mineral. Petrol., 155, 433-456, doi:10.1007/s00410-007-0251-3.

Sakuyama, M., and R. W. Nesbitt (1986), Geochemistry of the Quaternary volcanic rocks of the Northeast Japan arc, J. Volcanol. Geotherm. Res., 29, 413-450, doi:10.1016/0377-0273 (86)90053-3.

Salters, V. M., and A. Stracke (2004), Composition of the depleted mantle, Geochem. Geophys. Geosyst., 5, Q05B07, doi:10.1029/2003GC000597.

Schmidt, M. W., D. Vielzeuf, and E. Auzanneau (2004), Melting and dissolution of subducting crust at high pressures: The key role of white mica, Earth Planet. Sci. Lett., 228, 65-84, doi:10.1016/j.epsl.2004.09.020.

Seno, T., S. Stein, and A. E. Gripp (1993), A model for the motion of the Philippine Sea Plate consistent with NUVEL-1 and geological data, J. Geophys. Res., 98, 17,941-17,948.

Shibata, T., and E. Nakamura (1997), Across-arc variations of isotope and trace element compositions from Quaternary basaltic volcanic rocks in northeastern Japan: Implications for interaction between subducted oceanic slab and mantle wedge, J. Geophys. Res., 102(B4), 8051-8064, doi:10.1029/ 96JB03661.

Spandler, C., J. Hermann, R. Arculus, and J. Mavrogenes (2004), Geochemical heterogeneity and element mobility in deeply subducted oceanic crust; insights from high-pressure mafic rocks from New Caledonia, Chem. Geol., 206, 21-42, doi:10.1016/j.chemgeo.2004.01.006.

Stern, R. J., M. J. Fouch, and S. L. Klemperer (2003), An overview of the Izu-Bonin-Mariana subduction factory, in Inside the Subduction Factory, Geophys. Monogr. Ser., vol. 138, edited by J. Eiler, pp. 175-222, AGU, Washington, D. C.

Stolper, E. M., and S. Newman (1994), The role of water in the petrogenesis of Mariana trough magmas, Earth Planet. Sci. Lett., 121, 293-325, doi:10.1016/0012-821X(94)90074-4.

Straub, S. M., and G. D. Layne (2003), The systematics of chlorine, fluorine, and water in Izu arc front volcanic rocks: Implications for volatile recycling in subduction zones, Geochim. Cosmochim. Acta, 67, 4179-4203, doi:10.1016/ S0016-7037(03)00307-7.

Sun, S., and W. F. McDonough (1989), Chemical and isotopic systematics of oceanic basalts: Implications for mantle composition and processes, Geol. Soc. Spec. Publ., 42, 313-345.

Syracuse, E. M., P. E. v. Keken, and G. A. Abers (2010), The global range of subduction zone thermal models, Phys. Earth Planet. Inter., doi:10.1016/j.pepi.2010.02.004, in press.

Takahashi, E. (1986), Origin of basaltic magmas-Implications from peridotite melting experiments and an olivine fractionation model, J. Volcanol. Soc. Jpn., 20, S17-S40.

Tamura, Y., K. Tani, Q. Chang, H. Shukuno, H. Kawabata, O. Ishizuka, and S. Fiske (2007), Wet and dry basalt magma evolution at Torishima volcano, Izu-Bonin arc, Japan: The possible role of phengite in the downgoing slab, J. Petrol., 48, 1999-2031, doi:10.1093/petrology/egm048.

Tatsumi, Y., and S. Eggins (1995), Subduction Zone Magmatism, 211 pp., Blackwell Sci., Cambridge, Mass.
Tatsumi, Y., M. Sakuyama, H. Fukuyama, and I. Kushiro (1983), Generation of basaltic magmas and thermal structure of the mantle wedge in subduction zone, J. Geophys. Res., 88, 5815-5825, doi:10.1029/JB088iB07p05815.

Tatsumi, Y., T. Takahashi, Y. Hirahara, Q. Chang, T. Miyazaki, J.-I. Kimura, M. Ban, and A. Sakayori (2008), New Insights into andesite genesis: The role of mantle-derived calc-alkalic and crust-derived tholeiitic melts in magma differentiation beneath Zao Volcano, NE Japan, J. Petrol., 49, 1971-2008, doi:10.1093/petrology/egn055.

Taylor, R. N., and R. W. Nesbitt (1998), Isotopic characteristics of subduction fluids in an intra-oceanic setting, IzuBonin Arc, Japan, Earth Planet. Sci. Lett., 164, 79-98, doi:10.1016/S0012-821X(98)00182-4.

Taylor, S. R., and S. M. McLennan (1985), The Continental Crust: Its Composition and Evolution, 312 pp., Blackwell Sci., Oxford, U. K.

Tollstrup, D. L., and J. B. Gill (2005), Hafnium systematics of the Mariana arc: Evidence for sediment melt and residual phases, Geology, 33, 737-740, doi:10.1130/G21639.1.

Tollstrup, D., J. B. Gill, A. J. R. Kent, D. Prinkey, R. Williams, Y. Tamura, and O. Ishizuka (2010), Across-arc geochemical trends in the Izu-Bonin arc: Contributions from the subducting slab, revisited, Geochem. Geophys. Geosyst., 11, Q01X10, doi:10.1029/2009GC002847.

Turner, S., C. J. Hawkesworth, N. Rogers, J. Bartlett, T. Worthington, J. Hergt, J. A. Pearce, and I. M. E. Smith (1997), ${ }^{238} \mathrm{U}^{230}$ Th disequilibria, magma petrogenesis, and flux rates beneath the depleted Tonga-Kermadec island arc, Geochim. Cosmochim. Acta, 61, 4855-4884, doi:10.1016/ S0016-7037(97)00281-0.

Wallace, P. J. (2005), Volatiles in subduction zone magmas: Concentrations and fluxes based on melt inclusion and volcanic gas data, J. Volcanol. Geotherm. Res., 140, 217-240, doi:10.1016/j.jvolgeores.2004.07.023.

Woodhead, J., S. Eggins, and J. Gamble (1993), High field strength and transition element systematics in island arc and back-arc basin basalts: Evidence for multi-phase melt extraction and a depleted mantle wedge, Earth Planet. Sci. Lett., 114, 491-504, doi:10.1016/0012-821X(93)90078-N.

Woodhead, J. D., J. M. Hergt, J. P. Davidson, and S. M. Eggins (2001), Hafnium isotope evidence for 'conservative' element mobility during subduction zone processes, Earth Planet. Sci. Lett., 192, 331-346, doi:10.1016/S0012-821X(01)00453-8.

Workman, R. K., and S. R. Hart (2005), Major and trace element composition of the depleted MORB mantle (DMM), Earth Planet. Sci. Lett., 231, 53-72, doi:10.1016/j.epsl.2004.12.005. Yogodzinski, G. M., J. M. Lees, T. G. Churikova, F. Dorendorf, G. Wöerner, and O. N. Volynets (2001), Geochemical evidence for the melting of subducting oceanic lithosphere at plate edges, Nature, 409, 500-504, doi:10.1038/35054039.

Zou, H. (1998), Trace element fractionation during modal and nonmodal dynamic melting and open-system melting: A mathematical treatment, Geochim. Cosmochim. Acta, 62, 1937-1945, doi:10.1016/S0016-7037(98)00115-X. 